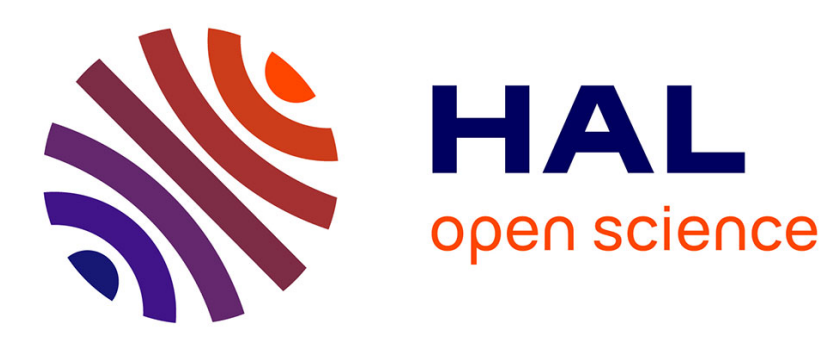

\title{
Bridging the Transuranics with Uranium(IV) Sulfate Aqueous Species and Solid Phases
}

\author{
Ian Colliard, Clement Falaise, May Nyman
}

\section{To cite this version:}

Ian Colliard, Clement Falaise, May Nyman. Bridging the Transuranics with Uranium(IV) Sulfate Aqueous Species and Solid Phases. Inorganic Chemistry, 2020. hal-03018170

\section{HAL Id: hal-03018170 https://hal.science/hal-03018170}

Submitted on 30 Dec 2020

HAL is a multi-disciplinary open access archive for the deposit and dissemination of scientific research documents, whether they are published or not. The documents may come from teaching and research institutions in France or abroad, or from public or private research centers.
L'archive ouverte pluridisciplinaire HAL, est destinée au dépôt et à la diffusion de documents scientifiques de niveau recherche, publiés ou non, émanant des établissements d'enseignement et de recherche français ou étrangers, des laboratoires publics ou privés. 


\title{
Bridging the Transuranics with Uranium(IV) Sulfate Aqueous Species and Solid Phases
}

\author{
Ian Colliard, Clement Falaise, ${ }^{\ddagger}$ and May Nyman*
}

Corresponding author: May Nyman may.nyman@oregonstate.edu

Department of Chemistry, Oregon State University, Corvallis, Oregon 97331, United States

${ }^{\ddagger}$ Present Address: C.F.: Institut Lavoisier de Versailles, UMR 8180, CNRS, UVSQ, Université Paris-Saclay,

Versailles, France

\begin{abstract}
Isolating isomorphic compounds of tetravalent actinides (i.e., $\mathrm{Th}^{\mathrm{IV}}, \mathrm{U}^{\mathrm{IV}}, \mathrm{Np}^{\mathrm{IV}}$, and $\mathrm{Pu}^{\mathrm{IV}}$ ) improve our understanding of the bonding behavior across the series, in addition to their relationship with tetravalent transition metals $(\mathrm{Zr}$ and Hf) and lanthanides (Ce). Similarities between these tetravalent metals are particularly illuminated in their hydrolysis and

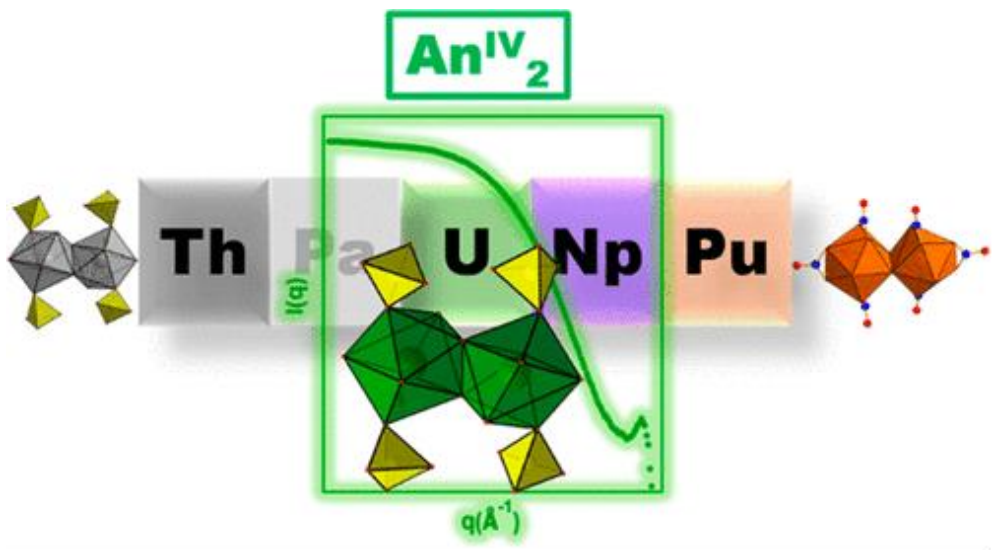
condensation behavior in aqueous systems, leading to polynuclear clusters typified by the hexamer $\left[\mathrm{M}^{\mathrm{IV}}{ }_{6} \mathrm{O}_{4}(\mathrm{OH})_{4}\right]^{12+}$ building block. Prior studies have shown the predominance and coexistence of smaller species for $\mathrm{Th}^{\mathrm{IV}}$ (monomers, dimers, and hexamers) and larger species for $\mathrm{U}^{\mathrm{IV}}, \mathrm{Np}^{\mathrm{IV}}$, and $\mathrm{Pu}^{\mathrm{IV}}$ (including 38-mers and 70-mers). We show here that aqueous uranium(IV) sulfate also displays behavior similar to that of $\mathrm{Th}^{\mathrm{IV}}$ (and $\mathrm{Zr}^{\mathrm{IV}}$ ) in its isolated solid-phase and solution speciation. Two single-crystal X-ray structures are described: a dihydroxide-bridged dimer $\left(\mathbf{U}_{2}\right)$ formulated as $\mathrm{U}_{2}(\mathrm{OH})_{2}\left(\mathrm{SO}_{4}\right)_{3}\left(\mathrm{H}_{2} \mathrm{O}\right)_{4}$ and a monomer-linked hexamer framework $\left(\mathbf{U}-\mathbf{U}_{6}\right)$ as $\left(\mathrm{U}_{(}\left(\mathrm{H}_{2} \mathrm{O}\right)_{3.5}\right)_{2} \mathrm{U}_{6} \mathrm{O}_{4}(\mathrm{OH})_{4}\left(\mathrm{SO}_{4}\right)_{10}\left(\mathrm{H}_{2} \mathrm{O}\right)_{9}$. These structures are similar to those previously described for $\mathrm{Th}^{\mathrm{IV}}$. Moreover, cocrystallization of monomer and dimer and of dimer and monomer-hexamer phases for both $\mathrm{Th}^{\mathrm{IV}}$ (prior) and $\mathrm{U}^{\mathrm{IV}}$ (current) indicates the coexistence of these species in solution. Because it was not possible to effectively study the sulfate-rich solutions via X-ray scattering from which $\mathbf{U}_{\mathbf{2}}$ and $\mathbf{U}_{-} \mathbf{U}_{\mathbf{6}}$ crystallized, we provide a parallel solution speciation study in low sulfate conditions, as a function of the $\mathrm{pH}$. Raman spectroscopy, UV-vis spectroscopy, and small-angle X-ray scattering of these show decreasing sulfate binding, increased hydrolysis, increased species size, and increased complexity, with increasing $\mathrm{pH}$. This study describes a bridge across the first half the actinide series, highlighting $\mathrm{U}^{\mathrm{IV}}$ similarities to $\mathrm{Th}^{\mathrm{IV}}$, in addition to the previously known similarities to the transuranic elements.
\end{abstract}




\section{INTRODUCTION}

Large tetravalent $\mathrm{M}^{\mathrm{IV}}$ cations (six-coordinate ionic radius $=0.85-1.1 \AA$ ), including transition metals $\left(\mathrm{Zr}^{\mathrm{IV}}\right.$ and $\left.\mathrm{Hf}^{\mathrm{IV}}\right)$, lanthanides $\left(\mathrm{Ce}^{\mathrm{IV}}\right)$, and actinides $\left(\mathrm{Th}^{\mathrm{IV}}, \mathrm{U}^{\mathrm{IV}}, \mathrm{Np}^{\mathrm{IV}}\right.$, and $\left.\mathrm{Pu}^{\mathrm{IV}}\right)$, exhibit rich polynuclear speciation in water, leading to the assembly of molecular nanoclusters, (1-6) inorganic frameworks, and metal-organic frameworks (MOFs, with added linkers).(7-9) This aqueous behavior is due to the strong Lewis and Brønsted acidity that promotes hydrolysis and condensation processes, even at $\mathrm{pH}<2$. For all of these metals, the most commonly observed species in solution and in the solid state is a hexamer; its core is generally formulated as $\left[\mathrm{M}^{\mathrm{IV}}{ }_{6} \mathrm{O}_{4}(\mathrm{OH})_{4}\right]^{12+}$. The hexamer is also the core building unit for $\mathrm{M}^{\mathrm{IV}} \mathrm{O}_{2}$ with fluorite topology. To isolate the hexamer as a solid, the appropriate capping groups are required, which include acetates and amino acids (molecular clusters), $(1,4,10)$ ditopic carboxylate linkers (MOFs), (7-9) or sulfates (frameworks or clusters).(11-13) While the $\mathrm{M}^{\mathrm{IV}}$ hexamer has been isolated numerous times, understanding the reaction steps from the dissolved $\mathrm{M}^{\mathrm{IV}}$ monomer to the hexamer via solution and solid-state characterization provides an opportunity to better control or redirect the reaction toward new synthons and to understand the aqueous behavior of metal cations in natural systems.

Defining aqueous hydrolysis/olation/oxolation and coordination chemistry of the tetravalent actinides $\mathrm{Th}^{\mathrm{IV}}, \mathrm{U}^{\mathrm{IV}}, \mathrm{Np}^{\mathrm{IV}}$, and $\mathrm{Pu}^{\mathrm{IV}}$ (the most common oxidation state of the early actinides) presents an opportunity to develop a better description of their bonding behavior. It is hypothesized that crossover of the $5 \mathrm{f}$ and $6 \mathrm{~d}$ frontier orbitals on the energy scale underlies the rich redox and coordination chemistry of the actinide series.(14-17) Thus, the early actinides are more similar to the transition metals, while the late actinides resemble the lanthanides. Beyond the $\mathrm{An}^{\mathrm{IV}}$-monomer cation, an oxo- or hydroxyl-linked dimer is the simplest subunit of the hexamer and also represents very early nucleation of $\mathrm{AnO}_{2}$ from $\mathrm{An}^{\mathrm{IV}}\left(\mathrm{H}_{2} \mathrm{O}\right)_{n}(n=8-10)$. As an example, a hydroxyl or an oxo bridge between the metal centers is formed by the following fundamental steps for $\mathrm{M}^{\mathrm{IV}}:(18)$

$$
\begin{aligned}
& \left.\mathrm{H}_{2} \mathrm{O}+\left[\left(\mathrm{H}_{2} \mathrm{O}\right)_{n} \mathrm{M}\right]^{4+} \rightarrow\left[\mathrm{HO}\left(\mathrm{H}_{2} \mathrm{O}\right)_{n-1} \mathrm{M}\right]^{3+}+\mathrm{H}_{3} \mathrm{O}^{+} \text {(hydrolysis; } n \sim 8-10\right) \\
& {[\mathrm{HO}-\mathrm{M}]^{3+}+\left[\mathrm{H}_{2} \mathrm{O}-\mathrm{M}\right]^{4+} \rightarrow[\mathrm{M}(\mathrm{OH}) \mathrm{M}]^{7+}+\mathrm{H}_{2} \mathrm{O} \text { (olation) }} \\
& {[\mathrm{M}-\mathrm{OH}]^{3+}+[\mathrm{HO}-\mathrm{M}]^{3+} \rightarrow[\mathrm{M}(\mathrm{O}) \mathrm{M}]^{6+}+\mathrm{H}_{2} \mathrm{O} \text { (oxolation) }}
\end{aligned}
$$

Dimers are commonly bridged by two or more hydroxyls. $\mathrm{Th}^{\mathrm{IV}}$ is considered to be the "softest" of the $\mathrm{An}^{\mathrm{IV}}$ series, and thus the least acidic. The dihydroxide- and trihydroxide-bridged $\mathrm{Th}_{2}$ dimers have been isolated numerous times with various coordinating ligands.(2) More relevant to this current study, the sulfate-capped $\mathrm{Th}^{\mathrm{IV}}$ dimers have been observed in solution and isolated in the solid state.(19-21) Recently, several intricate thorium sulfate frameworks that feature monomers, dimers, and hexamers have been structurally characterized, $(12,13)$ suggesting the coexistence of these species in solution. In addition, a $\mathrm{Th}_{3}$ trimer has recently been isolated.(22) On the other hand, the higher acidity of $\mathrm{Pu}^{\mathrm{IV}}$ promotes the formation of larger molecular clusters, including $\mathrm{Pu}_{16}$,(23) $\mathrm{Pu}_{22},(23)$ and $\mathrm{Pu}_{38},(24)$ in addition to the ubiquitous hexamer as isolated clusters(10) and, more recently, within a MOF framework.(25) Different from thorium, the diplutonium(IV) dihydroxide bridged dimer is more elusive, isolated only once, with nitrate ligands,(26) and, more recently, singly bridged via an oxo ligand also with nitrate ligands.(27) On the basis of large isolatable clusters including $\mathrm{U}_{38}(28-30)$ and $\mathrm{Np}_{38}(31)$ (in addition to numerous examples of 
hexamers, i.e., refs (5) and (32-35), the polymerization of $\mathrm{U}^{\mathrm{IV}}$ and $\mathrm{Np}^{\mathrm{IV}}$ appear to be more similar to $\mathrm{Pu}^{\mathrm{IV}}$ than $\mathrm{Th}^{\mathrm{IV}}$. Unlike $\mathrm{Pu}_{38}, \mathrm{~Np}_{38}$ and $\mathrm{U}_{38}$ isolation required organic media that slow olationoxolation reactions.(36) In addition, neither the $\mathrm{Np}^{\mathrm{IV}}{ }_{2}$ nor $\mathrm{U}^{\mathrm{IV}}{ }_{2}$ dimer has been isolated, from either water or organic media. In 1973, however, the dihydroxide-bridged $\mathrm{U}_{2}$ dimer was proposed in Xray scattering analysis of uranium(IV) perchlorate solutions.(37)

Motivations to study $\mathrm{U}^{\mathrm{IV}}$ aqueous chemistry go beyond understanding periodic table and f-element trends. It has been mined for more than a century, initially for isolation of radium, second for production of weapon-grade uranium and plutonium, and then by production of fuel for nuclear energy. Fuel fabrication, reprocessing, separations, storage and disposal, retroactive treatment of legacy wastes, and environmental contamination motivate continued studies of uranium speciation. There is particular focus on aqueous and solid-state uranium(IV) sulfate chemistry in the industrial realm. Sulfuric acid is commonly used for in situ leaching, leading to the formation of postmining alteration minerals.(38) Additionally, sulfate- and iron-reducing bacteria in nature and in the laboratory promote $\mathrm{U}^{\mathrm{VI}}$-to- $\mathrm{U}^{\mathrm{IV}}$ reduction, by the formation of either $\mathrm{U}^{\mathrm{IV}}$ complexes or $\mathrm{UO}_{2}$ nanoparticles,(39) with sizes similar to that of $\mathrm{U}_{38}$. Recently, we have shown that simply combining uranium(IV) sulfate in water with transition-metal or lanthanide countercations leads to larger cluster forms (including $\mathrm{U}_{84}$ and $\mathrm{U}_{70}$ ) and heterometallic oxysulfate frameworks. $(40,41)$ In these intricate assemblies, the $\mathrm{U}_{6}$ hexamer remains the core building unit.

Here we expand the library of uranium(IV) sulfate species with the description of two new phases by single-crystal X-ray diffraction, as well as solution characterization studies. $\mathbf{U}_{-} \mathbf{U}_{6}$ is a $\mathrm{U}^{\mathrm{IV}}$ monomer-linked hexamer framework, and $\mathbf{U}_{2}$ is the "missing" $\mathrm{U}^{\mathrm{IV}}{ }_{2}$ dimer, providing another metric in the aqueous tetravalent actinide series, bridging the $\mathrm{Th}_{2}(19-21)$ dimer to the $\mathrm{Pu}_{2}(26)$ dimer. Because $\mathbf{U}-\mathbf{U}_{6}$ and $\mathbf{U}_{2}$ crystallize from heated solutions at $0.5 \mathrm{M} \mathrm{H}_{2} \mathrm{SO}_{4}$ concentration, it was not feasible to study their assembly pathways or solution speciation by benchtop X-ray scattering. Instead, we dissolved $\mathrm{U}\left(\mathrm{SO}_{4}\right)_{2}$ in water and control hydrolysis reactions via a $\mathrm{pH}$ increase. Raman spectroscopy and small-angle X-ray scattering (SAXS) show increasing size of polynuclear uranium(IV) oxyhydroxysulfate and decreasing sulfate ligation, corresponding with increasing $\mathrm{pH}$ instead of heat. Size and size distribution analysis of the SAXS data suggest mixtures of monomers, dimers, hexamers, and monomer/dimer-decorated hexamers; species similar to those isolated from sulfate-rich solutions. Powder X-ray diffraction (PXRD) of bulk solids from which single crystals of $\mathbf{U}_{\mathbf{2}}$ and $\mathbf{U}_{-} \mathbf{U}_{\mathbf{6}}$ are isolated show cocrystallization of monomers, dimers, and monomer-hexamer frameworks. Likely the coexistence of these species in their parent reaction solutions suggests a competition between strongly coordinating ligands with flexible binding modes (sulfate) and strong hydrolysis chemistry of acidic $\mathrm{U}^{\mathrm{IV}}$, which drives complexity. The dihydroxide-bridged $\mathbf{U}_{2}$ dimer presented here provides a missing link in aqueous $\mathrm{U}^{\mathrm{IV}}$ chemistry as the first step of hydrolysis chemistry that leads to the predominant hexamer. Moreover, the coexistence of phases featuring monomers, dimers, and hexamers provides a bridge from $\mathrm{Th}^{\mathrm{IV}}$ to the transuranics. Specifically, the uranium(IV) sulfate behavior documented here is akin to thorium(IV) sulfate chemistry, while prior $\mathrm{U}^{\mathrm{IV}}$ speciation studies show behavior more similar to the transuranics with the self-assembly of larger polynuclear clusters. 


\section{EXPERIMENTAL SECTION}

Caution! Although we are using depleted uranium (DU), it still possesses some radioactivity and it is a toxic heavy metal, so precautions with suitable care and protection for handling each substance have been followed.

\section{Materials}

$\mathrm{UO}_{2}\left(\mathrm{CH}_{3} \mathrm{COO}\right)_{2}$, concentrated $\mathrm{H}_{2} \mathrm{SO}_{4}$ (98\% Macron Fine Chemicals), and Millipore-filtered water with a resistance of $18.2 \mathrm{M} \Omega \cdot \mathrm{cm}$ was used as received in all reactions.

\section{Synthesis of $\mathrm{U}\left(\mathrm{SO}_{4}\right)_{2}$}

The uranium(IV) sulfate starting material was synthesized as previously described.(40,41) Briefly, $5.0 \mathrm{~g}(0.01 \mathrm{~mol})$ of uranyl acetate was dissolved in $75 \mathrm{~mL}$ of anhydrous ethanol. Concentrated sulfuric acid $(25 \mathrm{~mL})$ was added dropwise. After complete dissolution of the uranyl acetate, the solution was placed under UV light (390-400 nm, $15 \mathrm{~W})$ for 24-48 h. The uranium was reduced and precipitated as uranium sulfate. The green/purple powder was vacuum-filtered and washed with four $50 \mathrm{~mL}$ aliquots of ethanol. It is X-ray amorphous and has a formula of approximately $\mathrm{U}\left(\mathrm{SO}_{4}\right)_{2} \cdot 4 \mathrm{H}_{2} \mathrm{O}$. The powder was then stored in a desiccator. Raman $\left(\mathrm{cm}^{-1}\right)$ : sulfate and $\mathrm{U}-\mathrm{O}, 420$, 448, 491, 592, 616, 656; sulfate, 987 (shoulder), 1011, 1043. IR ( $\left.\mathrm{cm}^{-1}\right)$ : sulfate and U-O, 580, 649; sulfate, 950,1127 . The percent yield was $~ 95 \%$ based on uranium ( $5.6 \mathrm{~g})$.

\section{Synthesis of $\mathrm{U}_{2}(\mathrm{OH})_{2}\left(\mathrm{SO}_{4}\right)_{3}\left(\mathrm{H}_{2} \mathrm{O}\right)_{4}\left(\mathrm{U}_{2}\right)$}

$\mathrm{U}\left(\mathrm{SO}_{4}\right)_{2}(0.1 . \mathrm{g})$ was dissolved in $0.5 \mathrm{~mL}$ of $0.5 \mathrm{M} \mathrm{H}_{2} \mathrm{SO}_{4}$ in a $2 \mathrm{~mL}$ screwcap vial to give a concentration of $0.46 \mathrm{M} \mathrm{U}^{\mathrm{IV}}$. The vial was capped, placed in a sand bath, and heated at $75{ }^{\circ} \mathrm{C}$ in an oven for $24 \mathrm{~h}$. During the hydrothermal treatment, crystals of $\mathbf{U}_{\mathbf{2}}$ grew. The crystals were then filtered and washed with $2 \mathrm{~mL}$ of $0.5 \mathrm{M} \mathrm{HCl}$ to remove any soluble material, followed by repeated washing of $2 \mathrm{~mL}$ of water. The crystals were left to dry in vacuo. Raman $\left(\mathrm{cm}^{-1}\right)$ : sulfate and $\mathrm{U}-\mathrm{O}$, 270, 420, 440, 597, 620; sulfate, 1013 (shoulder), 1028. IR $\left(\mathrm{cm}^{-1}\right)$ : sulfate and U-O, 491, 591; sulfate, 1030, 1093; $\mathrm{H}_{2} \mathrm{O}, 3000-3500$ (broad), 1600. Percent yield was $\sim 67 \%$ based on uranium (0.07 g).

\section{Synthesis of $\left(\mathrm{U}\left(\mathrm{H}_{2} \mathrm{O}\right)_{4.5}\right)_{2} \mathrm{U}_{6}(\mathrm{OH})_{4}(\mathrm{O})_{4}\left(\mathrm{SO}_{4}\right)_{10}\left(\mathrm{H}_{2} \mathrm{O}\right)_{9}\left(\mathrm{U}-\mathrm{U}_{6}\right)$}

$\mathrm{U}\left(\mathrm{SO}_{4}\right)_{2}(0.2 \mathrm{~g})$ was dissolved in $0.5 \mathrm{~mL}$ of $0.5 \mathrm{M} \mathrm{H}_{2} \mathrm{SO}_{4}$ in a $2 \mathrm{~mL}$ screwcap vial to give a concentration of $0.92 \mathrm{M} \mathrm{U}^{\mathrm{IV}}$. The vial was capped, placed in a sand bath, and heated at $75^{\circ} \mathrm{C}$ in an oven for $24 \mathrm{~h}$. During the hydrothermal treatment, crystals of $\mathbf{U}-\mathbf{U}_{\mathbf{6}}$ grew. The crystals were then filtered and washed with $2 \mathrm{~mL}$ of $0.5 \mathrm{M} \mathrm{HCl}$ to remove any soluble material, followed by 2 $\mathrm{mL}$ of water. The crystals were left to dry in vacuum. Raman $\left(\mathrm{cm}^{-1}\right)$ : sulfate and $\mathrm{U}-\mathrm{O}, 232,260$, 364, 436, 449, 493, 621, 633; sulfate, 1021, 1038, 1071. IR $\left(\mathrm{cm}^{-1}\right)$ : sulfate and U-O, 444, 595; sulfate, 1027, 1050; $\mathrm{H}_{2} \mathrm{O}, 3000-3200$ (broad), 1600. The percent yield was $\sim 45 \%$ based on uranium $(\sim 0.1 \mathrm{~g})$. 


\section{Spectroscopic Monitoring of $\mathrm{U}\left(\mathrm{SO}_{4}\right)_{2}$ Solutions}

A solution of sulfuric acid $\left(\mathrm{H}_{2} \mathrm{SO}_{4} ; 0.5 \mathrm{M}\right)$ was saturated with tetravalent uranium sulfate. Typically, around $1 \mathrm{~g}$ of $\mathrm{U}\left(\mathrm{SO}_{4}\right)_{2}\left(\mathrm{H}_{2} \mathrm{O}\right)_{n}$ was dissolved in $13.5 \mathrm{~mL}$ of diluted sulfuric acid, with a uranium concentration of around $0.15 \mathrm{M}$. A total of $200 \mu \mathrm{L}$ of the $\mathrm{U}^{\mathrm{IV}} / \mathrm{SO}_{4}$ solution were mixed with $800 \mu \mathrm{L}$ of distilled water $\left(\left[\mathrm{U}^{\mathrm{IV}}\right] \sim 30 \mathrm{mM}\right)$. Then a $\mathrm{NaOH}$ solution $(12.5 \mathrm{wt} \%)$ was added to the diluted $\mathrm{U}^{\mathrm{IV}} / \mathrm{SO}_{4}$ solution $(50,100,150,175,200,225$, and $250 \mu \mathrm{L})$. The $\mathrm{pH}$ values of the resulting solutions are respectively 1.78 (initial), 1.92, 1.95, 2.15, 2.25, 2.40, and 2.60. Raman spectroscopy and UV-vis spectroscopy were recorded for each solution.

\section{Crystallographic Studies}

U-U 6 crystals were collected on a Bruker DUO-APEX II CCD area detector at $173 \mathrm{~K}$ using $\mathrm{Cu}$ radiation $(\lambda=1.54178 \AA)$. Data reduction was accomplished using SAINT V8.34a. $\mathbf{U}_{2}$ was collected on a Rigaku Oxford Synergy $S$ at $100 \mathrm{~K}$ equipped with a PhotonJet S Cu source $(\lambda=1.54178 \AA)$ and a hyPix-6000HE photon counting detector. All images were collected and processed using CrysAlisPro, version 171.40_64.53 (Rigaku Oxford Diffraction, 2018). After integration, both (analytical) absorption and empirical absorption (spherical harmonic, image scaling, and detector scaling) corrections were applied.(42) All structures were solved by the intrinsic phasing method from SHELXT,(43) developed by successive difference Fourier syntheses, and refined by fullmatrix least squares on all $F^{2}$ data using SHELX(42) via the OLEX2 interface.(44)

Several A-level alerts resulted from strong absorption of the crystal. Empirical absorption correction was applied before frame scaling. Several other methods were employed before ultimately using analytical absorption correction for $\mathbf{U}_{\mathbf{2}}$ and "Multi-scan" for $\mathbf{U}-\mathbf{U}_{\mathbf{6}}$ using the $S C A L E 3$ ABSPACK.(45) This gave an $R_{\text {int }}$ value after absorption correction for $\mathbf{U}_{\mathbf{2}}$ of $9.43 \%$ (from $10.20 \%$ ) and for $\mathbf{U}_{-} \mathbf{U}_{6}$ of $6.98 \%$ (from $8.56 \%$ ). Nevertheless, a large residual electron density of less than $1 \AA$ away from the $U$ atoms remained. For $\mathbf{U}_{2}$, the largest residual peak is $-5.1 \AA^{-3}, 0.930$ $\AA$ from the $\mathrm{U}$ site, and for $\mathbf{U}_{-} \mathbf{U}_{6}$, the largest residual peak is $3.7 \AA^{-3}, 0.644 \AA$ away from U1B. All non-H atoms were refined anisotropically with the exception of the aqua ligands on U1B for the U-U6 structure because of the positional disorder of the monomer. This resulted in large prolated $\mathrm{O}$ atoms that could not be modeled independently, even from data collected at $173 \mathrm{~K}$, used to limit thermal motion. Crystallographic information and additional structural information are provided in Table 1. Supporting information is available in CIF format for $\mathbf{U}_{\mathbf{2}}$ and $\mathbf{U}-\mathbf{U}_{\mathbf{6}}$.

Table 1. Crystallographic Information for $\mathbf{U}_{2}$ and $\mathbf{U}-\mathbf{U}_{6}$

\begin{tabular}{|c|c|c|}
\hline identification code & $\mathbf{U}_{2}$ & $\mathbf{U}_{-} \mathbf{U}_{6}$ \\
\hline CCDC & 2015781 & 2015780 \\
\hline empirical formula & $\mathrm{H}_{10} \mathrm{O}_{18} \mathrm{~S}_{3} \mathrm{U}_{2}$ & $\mathrm{O}_{128} \mathrm{~S}_{20} \mathrm{U}_{16}$ \\
\hline molecular formula & $\mathrm{U}_{2}(\mathrm{OH})_{2}\left(\mathrm{SO}_{4}\right)_{3}\left(\mathrm{H}_{2} \mathrm{O}\right)_{4}$ & $\left.\left(\mathrm{U}_{2} \mathrm{H}_{2} \mathrm{O}\right)_{3.5}\right)_{2} \mathrm{U}_{6} \mathrm{O}_{4}(\mathrm{OH})_{4}\left(\mathrm{SO}_{4}\right)_{10}\left(\mathrm{H}_{2} \mathrm{O}\right)_{9}$ \\
\hline fW & 870.32 & 6497.68 \\
\hline temperature/ $\mathrm{K}$ & $100(2)$ & $172(2)$ \\
\hline cryst syst & monoclinic & tetragonal \\
\hline space group & $C 2 / c$ & $I \overline{42} d$ \\
\hline$a / \AA$ & $13.5620(2)$ & $21.2076(5)$ \\
\hline$b / \AA$ & $6.78250(10)$ & $21.2076(5)$ \\
\hline$c / \AA$ & $15.5926(2)$ & $11.9257(3)$ \\
\hline$\alpha / \mathrm{deg}$ & 90 & 90 \\
\hline$\beta / \mathrm{deg}$ & $95.6200(10)$ & 90 \\
\hline$\gamma / \mathrm{deg}$ & 90 & 90 \\
\hline
\end{tabular}




\begin{tabular}{|c|c|c|}
\hline volume $/ \AA^{3}$ & $1427.38(4)$ & $5363.7(3)$ \\
\hline$Z$ & 4 & 2 \\
\hline$\rho_{\text {calc }} /\left(\mathrm{g} / \mathrm{cm}^{3}\right)$ & 4.05 & 4.023 \\
\hline$\mu / \mathrm{mm}^{-1}$ & 68.486 & 71.976 \\
\hline$F(000)$ & 1544 & 5632 \\
\hline cryst size $/ \mathrm{mm}^{3}$ & $0.159 \times 0.108 \times 0.073$ & $\mathrm{Cu} \mathrm{K \alpha}(\lambda=1.54184)$ \\
\hline radiation & $\mathrm{Cu} \mathrm{K \alpha}(\lambda=1.54184)$ & $8.338-135.322$ \\
\hline $2 \theta$ range for data collection $/ \mathrm{deg}$ & $11.404-133.2$ & 34172 \\
\hline index ranges & $-16 \leq h \leq+16,-8 \leq k \leq+8,-18 \leq l \leq+18$ & $-25 \leq h \leq+24,-25 \leq k \leq+23,-14 \leq l \leq+14$ \\
\hline reflns collected & 13963 & $2423 / 0 / 198$ \\
\hline indep reflns & $1254\left[R_{\text {int }}=0.0943 ; R_{\sigma}=0.0326\right]$ & 1.078 \\
\hline data/restraints $/$ param & $1254 / 0 / 105$ & $2423\left[R_{\text {int }}=0.0698 ; R_{\sigma}=0.0275\right]$ \\
\hline GOF on $F^{2}$ & 1.196 & $R_{1}=0.0397 ; w R_{2}=0.1084$ \\
\hline final $R$ indexes $[I \geq 2 \sigma(I)]$ & $R_{1}=0.0381 ; w R_{2}=0.0940$ & $R_{1}=0.0404 ; w R_{2}=0.1095$ \\
\hline final $R$ indexes $($ all data $)$ & $R_{1}=0.0395 ; w R_{2}=0.0943$ & $3.74 /-1.62$ \\
\hline largest diff peak $/$ hole $/\left(\mathrm{e} / \AA^{3}\right)$ & $1.83 /-5.08$ & $0.015(10)$ \\
\hline Flack parameter & & \\
\hline
\end{tabular}

\section{PXRD}

Samples for PXRD were prepared by filtering and washing freshly synthesized crystals of the mixed products. The crystals of each sample were ground in a mortar and pestle. PXRD patterns were collected from 3 to $50^{\circ} 2 \theta$ at a rate of $1.5^{\circ} / \mathrm{min}$, using a Rigaku Miniflex with $\mathrm{Cu} \mathrm{K} \alpha$ radiation $(\lambda=1.54056 \AA)$.

\section{SAXS}

SAXS data were collected on an Anton Parr SAXSess instrument utilizing $\mathrm{Cu} \mathrm{K} \alpha$ radiation and line collimation. Data were recorded on an image plate in the range of $0.008-2.5 \AA^{-1}$. The sampleto-image plate distance was $26.1 \mathrm{~cm}$. Solutions were measured in $1.5 \mathrm{~mm}$ glass capillaries. Water was used as the background, and scattering was measured for $30 \mathrm{~min}$. SAXSQUANT software was used for data collection and processing (normalization, primary beam removal, and background subtraction). All other data analyses were carried out with the IRENA macros within IGOR Pro.(46) Simulated scattering data were calculated using SolX.(47)

\section{Fourier Transform Infrared (FT-IR) Spectroscopy}

IR spectra were recorded in attenuated reflectance mode using a Thermo Scientific Nicolet iS10 FT-IR spectrometer.

\section{Raman Vibration Spectroscopy}

Raman spectra were recorded on a Thermo Scientific DXR spectrometer (fine laser power: powercontrolled and reported at samples in $0.1 \mathrm{~mW}$ increments) with a $760 \mathrm{~nm}$ laser source, between wavelengths of 100 and $1200 \mathrm{~cm}^{-1}$.

\section{Scanning Electron Microscopy (SEM) and Energy-Dispersive X-ray Spectroscopy (EDXS)}


Electron micrographs and atomic ratios (\%) of the crystalline materials were obtained from a Quanta 600F instrument (FEI) combining a scanning electron microscope and an energydispersive X-ray spectrometer.

\section{RESULTS and DISCUSSION}

\section{Synthesis and Characterization of $\mathrm{U}_{2}$ and $\mathrm{U}-\mathrm{U}_{6}$}

Two new uranium sulfate structures were isolated and characterized by single-crystal X-ray diffraction in this study. From a solution of $\sim 0.5 \mathrm{M} \mathrm{U}^{\mathrm{IV}}$ and $0.5 \mathrm{M} \mathrm{H}_{2} \mathrm{SO}_{4}$, heated at $75{ }^{\circ} \mathrm{C}$ (see the Experimental Section for details), we isolated crystals of the dihydroxide-bridged dimer $\mathbf{U}_{2}$. $\mathbf{U}_{2}$ is fully formulated as $\mathrm{U}_{2}(\mathrm{OH})_{2}\left(\mathrm{SO}_{4}\right)_{3}\left(\mathrm{H}_{2} \mathrm{O}\right)_{4}$ and crystallizes in the centrosymmetric monoclinic space group $C 2 / c$ (Table 1). The structure adopts a three-dimensional (3D) framework (Figure 1b) comprised of a dihydroxide-bridged dimeric $\mathrm{U}^{\mathrm{IV}}$ core $\left[\mathrm{U}_{2}(\mathrm{OH})_{2}\left(\mathrm{H}_{2} \mathrm{O}\right)_{4}\right]^{6+}$ (Figure 1a), analogous to previously reported dihydroxide-bridged thorium dimers. $(19,20)$ There is one crystallographically unique $\mathrm{U}^{\mathrm{IV}}$ center that is eight-coordinate, bound to four sulfates $\left[\mathrm{U}-\mathrm{OSO}_{3}=\right.$ 2.33(1)-2.37(1) $\AA]$, two hydroxides $[\mathrm{U}-\mathrm{OH}=2.21(1)-2.36(1) \AA]$, and two terminal water molecules $\left[\mathrm{U}-\mathrm{OH}_{2}=2.40(1)-2.42(1) \AA\right]$. The dimers are aligned approximately along the (101) direction, and the 3D lattice is created by sulfate bridging between dimers. There are two crystallographically unique sulfates: $\mathrm{S}(1)$ bridges three dimers, denoted as $\mu_{3}-\mathrm{SO}_{4}$, and $\mathrm{S}(2)$ bridges two dimers, $\mu_{2}-\mathrm{SO}_{4}$ (Figure $1 \mathrm{~b}$ ). Each dimer bridges to neighboring dimers by eight sulfates, four for each $\mathrm{U}$ center: three $\mathrm{S}(1) \mathrm{O}_{4}{ }^{2-}$ and one $\mathrm{S}(2) \mathrm{O}_{4}{ }^{2-}$. There is no disorder in this simple structure. Bond-valence-sum (BVS) calculations (Table $\mathrm{S} 1)$ readily distinguish hydroxyl (BVS = 1.27) from water (BVS 0.5) ligands and are consistent with a tetravalent oxidation state of uranium $(\mathrm{BVS}=4.3)$.

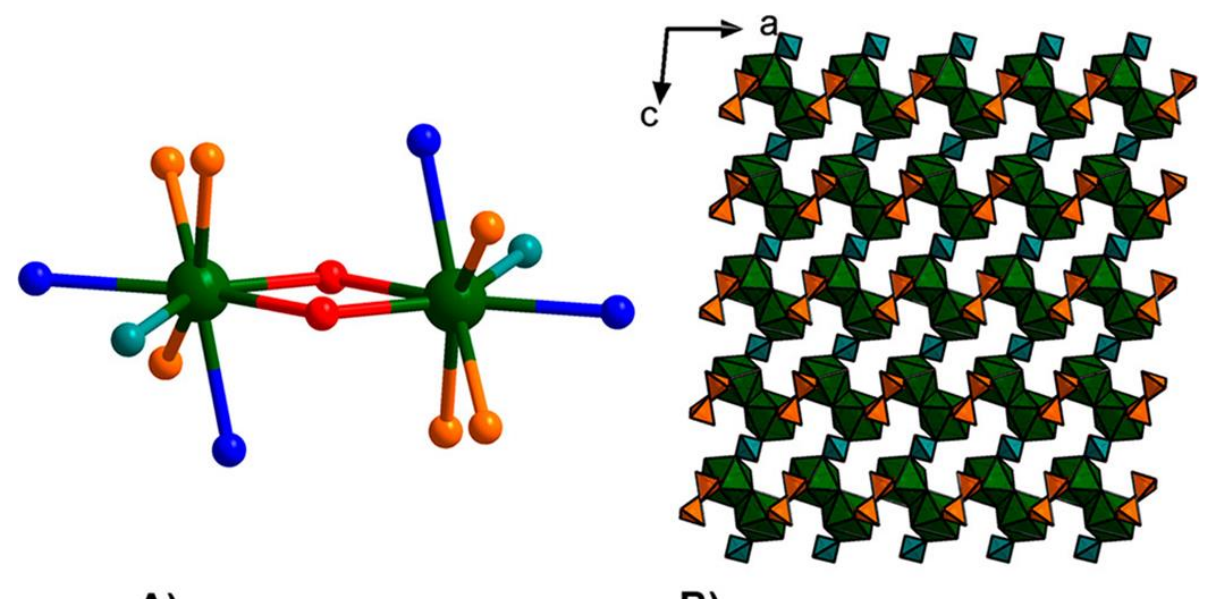

A)

B)

Figure 1. (A) Ball-and-stick representation of the $\left[\mathrm{U}_{2}(\mathrm{OH})_{2}\right]$ core. $\mathrm{U}^{\mathrm{IV}}$ is green, bridging $\mathrm{OH}^{-}$is red, $\mathrm{H}_{2} \mathrm{O}$ is blue, oxo of $\mu_{3}-\mathrm{SO}_{4}$ is orange, and oxo of $\mu_{2}-\mathrm{SO}_{4}$ is turquoise. (B) Polyhderal representation of the extended framework, viewed down the $b$ axis. $\mathrm{U}^{\mathrm{IV}}$ is green, $\mu_{3}-\mathrm{SO}_{4}$ is orange, and $\mu_{2}-\mathrm{SO}_{4}$ is turquoise. 
We note that $\mathbf{U}_{2}$ has a transition-metal isostructural counterpart, $\mathrm{Zr}_{2}(\mathrm{OH})_{2}\left(\mathrm{SO}_{4}\right)_{3}\left(\mathrm{H}_{2} \mathrm{O}\right)_{4},(48)$ although the ionic radius of $\mathrm{M}^{\mathrm{IV}}$ differs significantly $\left(0.86\right.$ and $1.04 \AA$ for $\mathrm{Zr}^{\mathrm{IV}}$ and $\mathrm{U}^{\mathrm{IV}}$, respectively), suggesting that it is likely possible to isolate analogues with tetravalent $\mathrm{M}^{\mathrm{IV}}$ of intermediate ionic radii (e.g., $\mathrm{Hf}^{\mathrm{IV}}, \mathrm{Ce}^{\mathrm{IV}}, \mathrm{Np}^{\mathrm{IV}}$, and $\mathrm{Pu}^{\mathrm{IV}}$ ). Another related compound is the dihydroxide-bridged $\mathrm{M}^{\mathrm{IV}} 2$ dimer $\mathrm{M}^{\mathrm{IV}}(\mathrm{OH})_{2} \mathrm{SO}_{4}$ composed of infinite chains of dihydroxidebridged $\left[\mathrm{MO}_{8}\right](\mathrm{M}=\mathrm{Zr},(49) \mathrm{Hf},(50) \mathrm{Th},(19)$ and $\mathrm{U}(51))$. All of these hydroxide-bridged metal(IV) sulfate analogues exhibit 3D inorganic networks and are isolated by the hydrothermal treatment of aqueous metal(IV) sulfate solutions.

By doubling the $\mathrm{U}^{\mathrm{IV}}$ concentration to $\sim 1 \mathrm{M}$ (see the Experimental Section) in the reaction, we obtained the monomer-linked hexamer framework $\mathbf{U}-\mathbf{U}_{\mathbf{6}}$. The $\mathbf{U}-\mathbf{U}_{6}$ structure, fully formulated as $\left(\mathrm{U}\left(\mathrm{H}_{2} \mathrm{O}\right)_{3.5}\right)_{2} \mathrm{U}_{6} \mathrm{O}_{4}(\mathrm{OH})_{4}\left(\mathrm{SO}_{4}\right)_{10}\left(\mathrm{H}_{2} \mathrm{O}\right)_{9}$, crystallizes in the noncentrosymmetric tetragonal space group $I \overline{42} d$ (Table 1). The structure (Figure 2) is comprised of the well-known $\mathrm{U}^{\mathrm{IV}}$ hexameric core, $\left[\mathrm{U}_{6} \mathrm{O}_{4}(\mathrm{OH})_{4}\right]^{12+}$ arranged tetrahedrally in $3 \mathrm{D}$ space, bridged by four $\mathrm{U}^{\mathrm{IV}}$ monomers that surround the $\mathrm{U}_{6}$ core in a tetrahedral arrangement. The core exhibits no $\mathrm{O} / \mathrm{OH}$ disorder that is typical of isolated molecular clusters;(32) the rigid framework enforces ordering. The hydroxides and oxides are readily distinguished by BVS (Table $\mathrm{S} 2$ ). Each monomer bridges two $\mathrm{U}_{6}$ units, and all $\mathrm{U}_{1}-\mathrm{U}_{6}$ bridges are via sulfates. Each $\mathrm{U}^{\mathrm{IV}}$ center in the hexamer is bonded to two $\mu_{3}-\mathrm{O}[\mathrm{U}-\mathrm{O}=2.24(2)-$ 2.28(2) $\AA]$ and two $\mu_{3}-\mathrm{OH}[\mathrm{U}-\mathrm{OH}=2.46(2) \AA]$ of the core $\mathrm{U}_{6} \mathrm{O}_{4}(\mathrm{OH})_{4}$ unit, plus four bridging sulfates $\left[\mathrm{U}-\mathrm{OSO}_{3}=2.39(2)-2.42(2) \AA\right]$ and one water molecule $\left[\mathrm{U}-\mathrm{OH}_{2}=2.62(2)-2.86(2) \AA\right]$, completing a nine-coordinate, capped square-antiprismatic geometry. Per the $\mathrm{U}_{6}$ unit, there are 8 fully occupied bridging sulfates and 4 half-occupied (disordered) sites (shown in Figure $2 \mathrm{a}$ ) for a total of 10 per formula unit. The monomer has considerable disorder in its ligand coordination and is, on average, eight-coordinate. The monomer bridges two hexamers. To each hexamer, the monomer links via one half-occupied sulfate $\left[\mathrm{U}-\mathrm{OSO}_{3}=2.55(1) \AA\right]$ and two fully occupied sulfates $\left[\mathrm{U}-\mathrm{OSO}_{3}=2.20(1) \AA\right]$. In addition to these six bonds to the uranium monomer, it is surrounded by eight partially occupied water positions $\left[\mathrm{U}-\mathrm{OH}_{2}=2.21(2)-2.62(2) \AA\right]$. BVS calculations (Table S2) of the $\mathrm{U}$ sites indicate good agreement with the $\mathrm{U}^{\mathrm{IV}}$ oxidation state for the two sites within the hexamer (4.0 and 4.1), but the value is slightly higher for the disordered monomer site (4.5). The geometry of the monomer and the reaction conditions do not support pentavalent uranium, and thus this apparent "overbonding" of the $\mathrm{U}^{\mathrm{IV}}$ monomer is attributed to the disorder. 

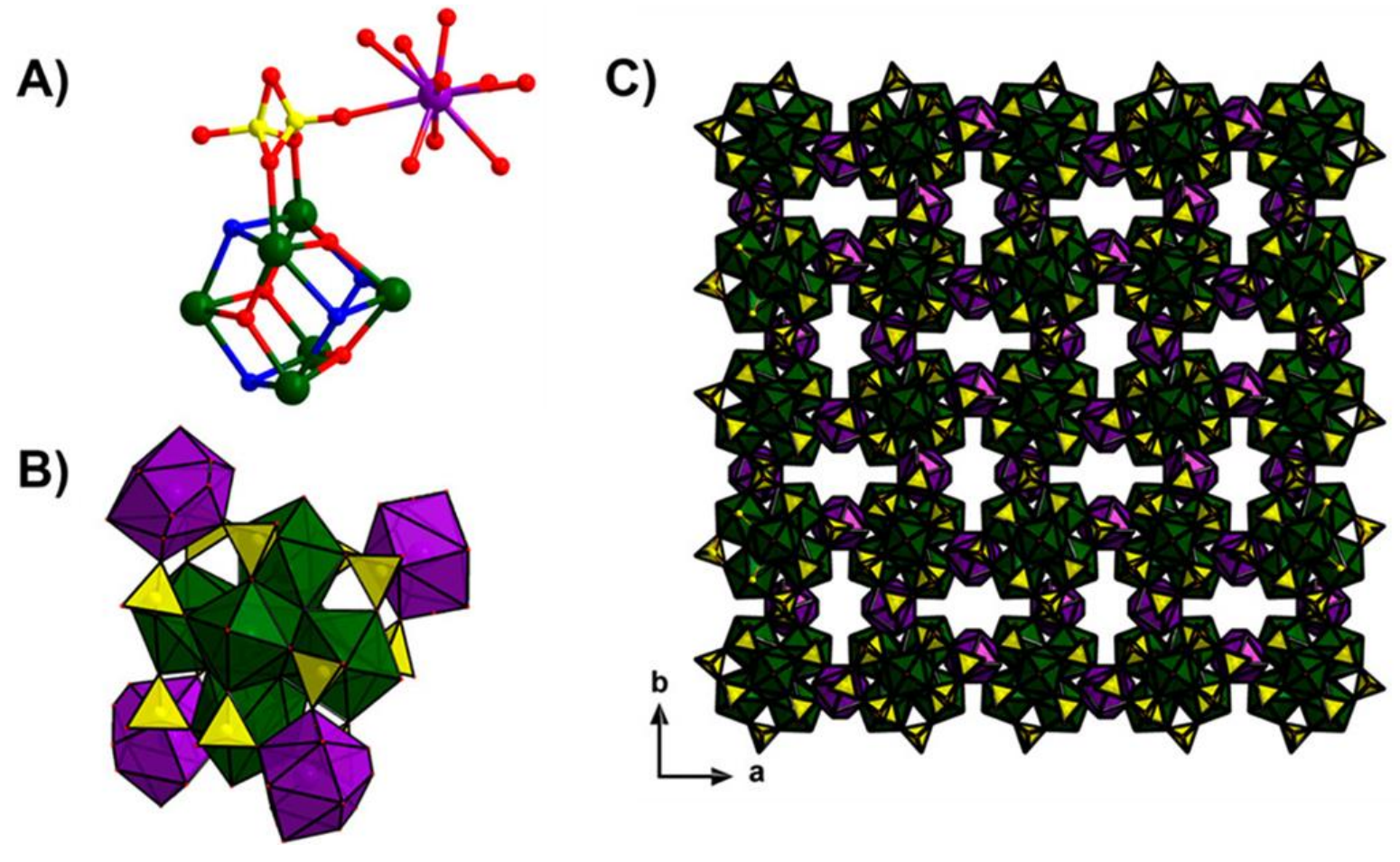

Figure 2. Representations of U-U6. (A) Ball-and-stick representation of the connectivity between the hexamer and monomer units via a disordered sulfate. For the $\mathrm{U}_{6} \mathrm{O}_{4}(\mathrm{OH})_{4}$ unit, $\mathrm{U}^{\mathrm{IV}}$ are green spheres, $\mathrm{O}^{2-}$ are red spheres, and $\mathrm{OH}^{-}$are blue spheres. The monomer $\mathrm{U}^{\mathrm{IV}}$ is purple, and $\mathrm{S}$ (disordered over two half-occupied sites) of bridging $\mathrm{SO}_{4}{ }^{2-}$ are yellow spheres. (B) Illustration of the tetrahedral arrangement of the monomers around the $\mathrm{U}_{6}$ unit. Purple polyhedra are the $\mathrm{U}^{\mathrm{IV}}$ monomers, green polyhedra are the $\mathrm{U}^{\mathrm{IV}}$ of the hexamer, and yellow polyhedra are sulfates. (C) Framework view down the $c$ axis. The color scheme is the same as that in part B.

U-U6 can be compared to the $\mathrm{U}_{6}$ framework reported in 1955 by Lundgren.(52) In the $\mathrm{U}_{6}$ framework, the $\mathrm{U}_{6}$ units are linked directly to each other via sulfates, without the monomer bridge. Each $\mathrm{U}_{6}$ has a scaffold of 4 bridging sulfates and 12 terminal sulfates, linking to 12 additional $\mathrm{U}_{6}$ units in an approximately closest-packed array of $\mathbf{U}_{6}$ "superatoms". The monomer unit of $\mathbf{U}_{-} \mathbf{U}_{6}$ opens up the framework, with only four neighboring hexamers per $U_{6}$ unit, and the $U_{1}$ units increasing the spacing between hexamer units. Channels are observed down the $c$ axis $(\sim 7 \AA$ diameter; Figure 2C). Because no strong peaks are located in this space, we assume it contains delocalized water molecules.

Raman spectra of solids $\mathbf{U}_{\mathbf{2}}$ and $\mathbf{U}-\mathbf{U}_{\mathbf{6}}$ are shown in Figure 3 for both the sulfate resonances between 950 and $1200 \mathrm{~cm}^{-1}$ and additional low-energy vibrations at $200-700 \mathrm{~cm}^{-1}$, which could be interpreted as either additional sulfate stretches and/or $\mathrm{U}-\mathrm{O}$ bond vibrations (Figure 3, inset, discussed later). The highest-intensity peaks between 1000 and $1050 \mathrm{~cm}^{-1}$ for both $\mathbf{U}_{2}$ and $\mathbf{U}_{-} \mathbf{U}_{6}$ were previously assigned as $\mathrm{A}_{1}$-symmetric stretches of sulfate by Schnaars and Wilson, while the broader peaks at $>1050 \mathrm{~cm}^{-1}$ were assigned as $T_{2}$-asymmetric sulfate stretches.(53) Both phases also exhibit intense peaks at lower frequency (inset), which were previously attributed to sulfate.(53) In all polyoxometalate (POM) systems, this region in IR and Raman spectra is attributed to $\mathrm{M}-\mathrm{O}$ stretches of the metal-oxo clusters, where vibrational frequencies increase with 
decreased bond length. Therefore, it is reasonable to expect $\mathrm{U}-\mathrm{O}$ vibrations in this low-frequency region as well. For these peaks, as well as the sulfate peaks, the $\mathbf{U}-\mathbf{U}_{\mathbf{6}}$ spectrum exhibits more complexity than $\mathbf{U}_{2}$, consistent with the higher number of crystallographically unique $\mathrm{U}^{\mathrm{IV}}$ sites (one for $\mathbf{U}_{\mathbf{2}}$ and three for $\mathbf{U}-\mathbf{U}_{\mathbf{6}}$ ). The corresponding IR spectra of $\mathbf{U}_{\mathbf{2}}$ and $\mathbf{U}-\mathbf{U}_{\mathbf{6}}$ are shown in Figure S1. These also exhibit greater complexity for the $\mathbf{U}-\mathbf{U}_{\mathbf{6}}$ phase in the strong sulfate vibrations (centered around $1000 \mathrm{~cm}^{-1}$ ) and $\mathrm{U}^{\mathrm{IV}}-\mathrm{O}$ vibrations. The unique stretch at $750 \mathrm{~cm}^{-1}$ for $\mathbf{U}_{2}$ is tentatively attributed to vibration of the unique $\mathrm{U}-(\mathrm{OH})_{2}-\mathrm{U}$ unit. In addition, the $\mathrm{OH}$ stretch of the bridging hydroxide is distinctive for $\mathbf{U}_{2}$.

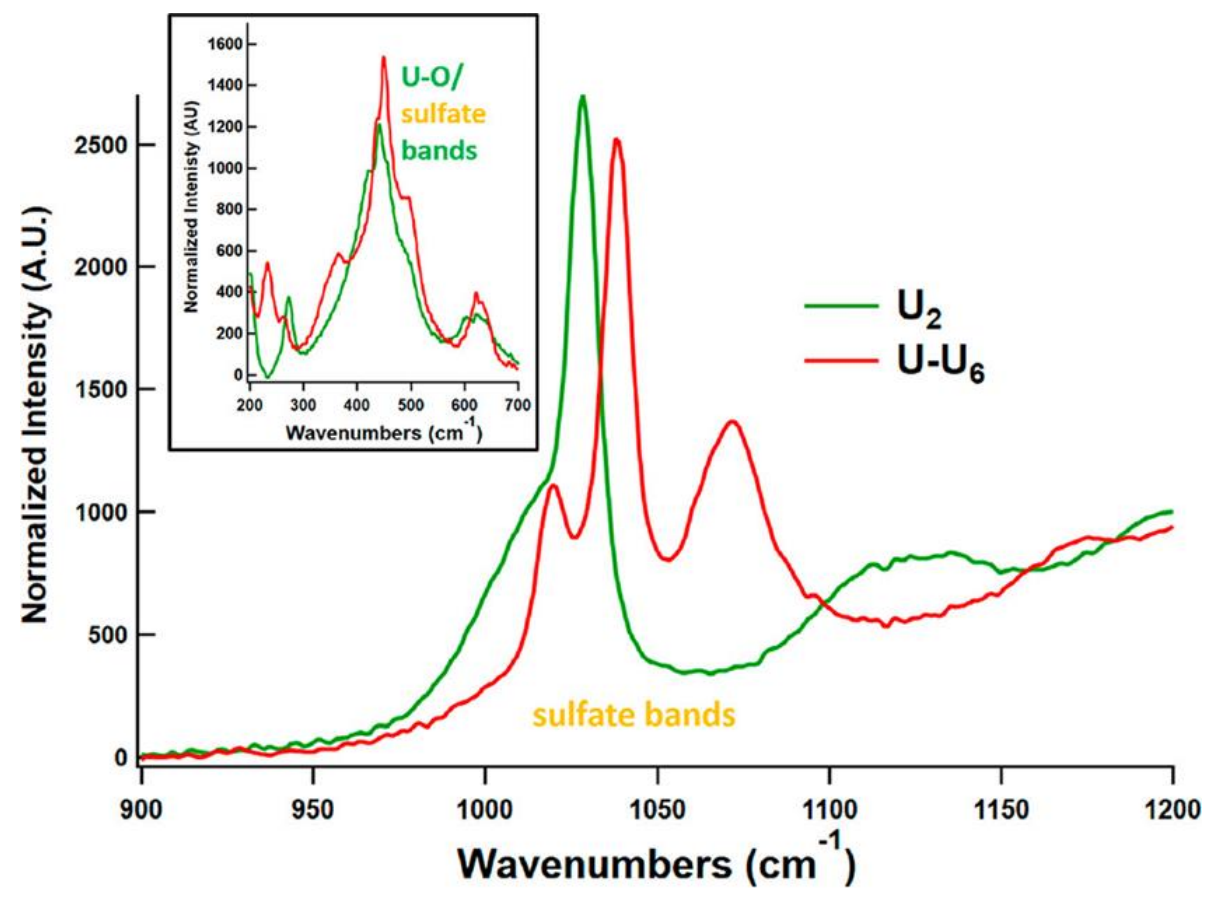

Figure 3. Raman spectra of solid $\mathbf{U}_{\mathbf{2}}$ and $\mathbf{U}-\mathbf{U}_{\mathbf{6}}$, emphasizing the sulfate vibrations and $\mathrm{U}-\mathrm{O} /$ sulfate vibrations (inset).

\section{Aqueous Speciation of Uranium(IV) Sulfate in Low-Ionic-Strength Solutions}

The high uranium and sulfate concentrations with commensurate high X-ray attenuation of the optimized $\mathbf{U}_{\mathbf{2}}$ and $\mathbf{U}_{-} \mathbf{U}_{\mathbf{6}}$ crystallization solutions, the required heating, and the poor solubility of species in these solutions precluded analysis by SAXS or Raman, either prior to heating or postprecipitation of the solid phase(s). Therefore, we carried out a separate solution-phase study to spectroscopically monitor the evolution of uranium sulfate species with changing $\mathrm{pH}$. The isolated solids provide models to characterize solution species, and it becomes evident that similar species could exist in both the high- and low-ionic-strength solutions, discussed later. With constant $\mathrm{U}\left(\mathrm{SO}_{4}\right)_{2}$ concentration $(30 \mathrm{mM}$ ), we varied the $\mathrm{pH}$ by adding $\mathrm{NaOH}$ (see the Experimental Section). With a starting $\mathrm{pH}$ of 1.7 (without added base), the solution was titrated up to 2.8, in approximately eight steps. Raman and UV-vis spectra were recorded. By Raman spectroscopy (Figure $4 \mathrm{~b}$ ), we observe two free sulfate stretches designated as $\mathrm{HSO}_{4}^{-}\left(1050 \mathrm{~cm}^{-1}\right)$ and $\mathrm{SO}_{4}{ }^{2-}(980$ $\mathrm{cm}^{-1}$ ), plus two U-SO 4 stretches at $1000 \mathrm{~cm}^{-1}$ (terminally bound or bridging) and $960 \mathrm{~cm}^{-1}$ (bidentate). These stretches are very similar and are assigned based on prior solution-phase studies 
of hafnium sulfate speciation.(54) Interestingly, the equivalent $\mathrm{SO}_{4}$-bound uranium peak positions identified in the solid state (discussed above) are shifted $\sim 50 \mathrm{~cm}^{-1}$ to lower frequency in solution. This is attributed to extensive hydrogen bonding of the $\mathrm{U}-\mathrm{SO}_{4}$ species with their solvation shells in solution, lengthening the $\mathrm{S}-\mathrm{O}$ bonds. With increasing $\mathrm{pH}$, the chelating $\mathrm{U}=\mathrm{O}_{2} \mathrm{SO}_{2}$ decreases in intensity and the terminally bound $\mathrm{U}-\mathrm{O}-\mathrm{SO}_{3}$ increases. These changes evidence increasing hydrolysis of $\mathrm{U}^{\mathrm{IV}}$, as $\mathrm{U}-\mathrm{OH}^{-} / \mathrm{O}^{2-}$ bonds replace uranium-sulfate bonds, which promotes oligomer formation. In conjunction, we observe deprotonation of $\mathrm{HSO}_{4}^{-}$with increasing $\mathrm{pH}$, as this peak disappears.

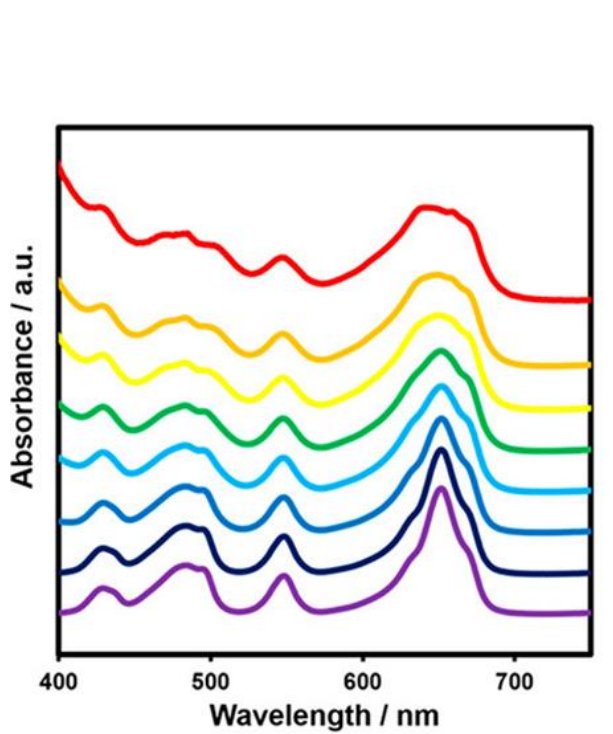

A)
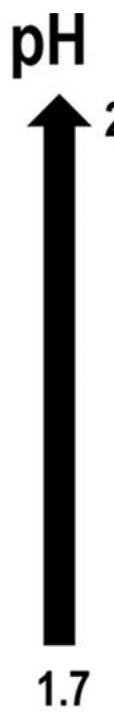

1.7

B)

Figure 4. UV-vis (A) and Raman (B) spectra of $30 \mathrm{mM} \mathrm{U}\left(\mathrm{SO}_{4}\right)_{2}$, with increasing $\mathrm{pH}$ from 1.7 (bottom) to 2.8 (top). Inset: Raman spectra showing two modes of sulfate bonding to $\mathrm{U}^{\mathrm{IV}}$ : chelating (blue box) and terminal/bridging (red box).

UV-vis spectroscopy showed the typical four bands for $\mathrm{U}^{\mathrm{IV}}$, indicating a purity of the oxidation state. The term symbols are labeled for the $\mathrm{pH} 1.7$ solution in Figure S2, following prior assignments of uranium(IV) sulfate solutions(55) and $\mathrm{U}^{\mathrm{IV}}$ in deuterated perchloric acid.(56) Ligand-field effects and speciation alter the intensity of these peaks but not the positions. However, with increasing hydrolysis and assembly of larger species (dimers, hexamers, etc., discussed below) with increasing $\mathrm{pH}$, the ${ }^{1} \mathrm{I}_{6}$ peak broadens and splits, and the ${ }^{3} \mathrm{P}_{0}$ and $\mathrm{D}_{2}$ peaks increase in intensity. This latter change was previously noted for the ingrowth of polynuclear complexes of uranium sulfate.(55)

SAXS (Figure 5A) data recorded for three $\mathrm{pH}$ values revealed strong and distinctive scattering of polynuclear forms. The flat low- $q\left(<0.2 \AA^{-1}\right)$ region indicates no aggregation for all three solutions. At $\mathrm{pH} 1.8$ (without added base), a comparison of the experimental scattering data to simulated scattering(47) indicates that the dimer form dominates this solution. However, the dissolved species are smaller than the dimer observed in the $\mathbf{U}_{\mathbf{2}}$ solid, with terminally bound and bridging sulfates (Figure 5B). Instead, the simulated scattering of either a $\mathrm{H}_{2} \mathrm{O} / \mathrm{OH}^{-}$-terminated species or a hypothetical dimer (created by Avogadro)(57) with mixed chelating sulfates and/or $\mathrm{H}_{2} \mathrm{O} / \mathrm{OH}^{-}$ ligands provided a close match to the experimental data. Although simulated scattering of the 
dimer without sulfates also provided an excellent match to the experimental data, the Raman data suggest that $\mathrm{U}^{\mathrm{IV}}$ with chelating sulfate is abundant in these solutions, in agreement with the proposed dimer species with mixed ligands (Figure 4B). We also simulated scattering data of a monomer with various numbers of sulfates, and two monomers bridged by a sulfate, but these did not provide as close a match as the two dimer forms.
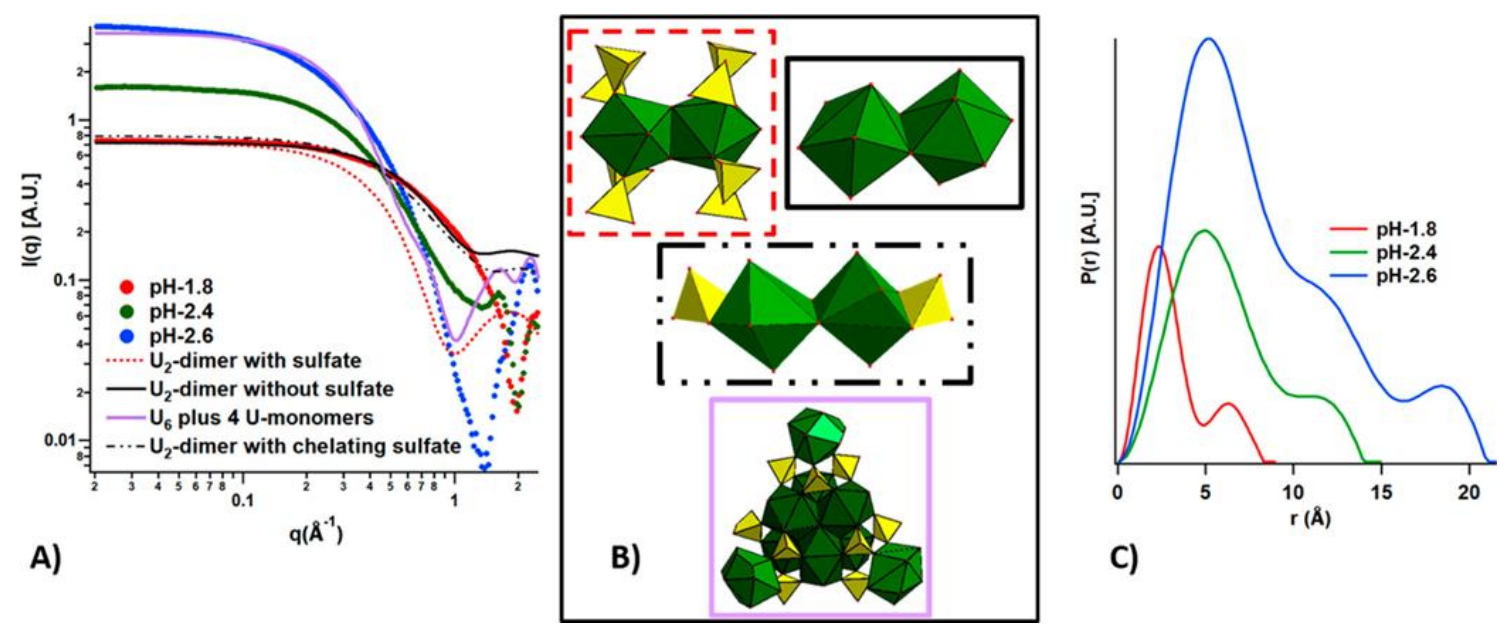

Figure 5. SAXS data and analyses. (A) log-log plot of the experimental (data points) and simulated (lines) scattering data. (B) Structures used for scattering data simulations. The frame matches the simulated scattering curve in part A. In the red box is precisely the dimer unit of $\mathbf{U}_{2}$ with all terminal/bridging sulfates, the solid black box shows the dimer with only $\mathrm{H}_{2} \mathrm{O} / \mathrm{OH}^{-}$ ligands, the broken black frame shows a hypothetical dimer capped with chelating sulfates, and the lavender box shows the core unit of $\mathbf{U}-\mathbf{U}_{\mathbf{6}}$, a hexamer with tetrahedrally arranged monomer caps. (C) PDDF representation of three scattering curves. $r$ is the distance from the edge of the scattering particle, and $P(r)$ is the probability of the scattering vector of length $r(\AA)$.

We can further solidify this interpretation by comparison to prior high-energy X-ray scattering (HEXS) studies of zirconium(58) and hafnium(59) sulfate solutions. Increasing the sulfate concentration increased species containing bidentate sulfate, but the zirconium sulfate monomer that precipitates from these solutions does not contain bidentate sulfate.(58) Similarly, HEXS provided strong evidence for bidentate coordination to hafnium, whereas no isolated solids contain this binding mode. We too observe evidence for bidentate-coordinated sulfate (by Raman and SAXS) in solution.

With increasing $\mathrm{pH}$, the uranium(IV) sulfate species grow, as evidenced by the shift in the Guinier elbow to lower $q\left(q \sim 0.3-0.8 \AA^{-1}\right.$ for $\mathrm{pH} 1.8$ and $q \sim 0.1-0.5 \AA^{-1}$ for $\left.\mathrm{pH} 2.6\right)$. The pair distance distribution functions (PDDFs, probability distribution maps of the scattering vectors through the clusters) of the three solutions (Figure 5C) indicate that the maximum diameters observed are 9, 14, and $24 \AA$, respectively, with increasing $\mathrm{pH}$. On the basis of a comparison to simulated scattering, the $\mathrm{pH} 2.6$ solution is dominated by species with the approximate size and shape of the hexamer decorated with four tetrahedrally arranged monomers, as observed in $\mathbf{U}-\mathbf{U}_{\mathbf{6}}$ (Figures $2 \mathrm{~A}$ and $5 \mathrm{~B})$. The intermediate solution ( $\mathrm{pH} 2.4)$ scattering does not precisely match any subunits of the described phases, but intermediate sizes observed in both the scattering data and PDDF suggest a mixture of hexamers capped with varying numbers of $U_{1}$ monomers and/or sulfate groups and 
possibly some dimer species. The PDDF profiles are all complex and could be interpreted in different ways. The $\mathrm{pH} 1.8$ solution exhibits the classic profile of a "dumbell" shape with a short dimension of $\sim 2.5 \AA$ (maximum of the first peak) and a long dimension of $8.5 \AA$ [maximum linear extent of PDDF, where the probability, $P(r)$, goes to 0$]$. Both the profile shape and dimensions are exactly consistent with a dihydroxide-bridged dimer, either with all $\mathrm{H}_{2} \mathrm{O} / \mathrm{OH}^{-}$termination or with chelating sulfates (both shown in Figure 5B). The PDDFs of the $\mathrm{pH} 2.4$ and 2.6 solutions indicate some complexity, suggesting some polydispersity of these uranium(IV) sulfate solutions, as discussed previously. In Soderholm's zirconium sulfate study, they also employed SAXS, which showed increasing species size up to $0.5 \mathrm{M}$ sulfate, followed by decreasing species size up to $2 \mathrm{M}$ sulfate. This was interpreted as the well-known $\mathrm{Zr}_{18}$ sulfate species dominating the $0.5 \mathrm{M}$ sulfate solution, whose assembly is inhibited as sulfate replaces oxo/hydroxyl bridges as sulfate is increased to 2.0 M.(58) Soderholm's study and prior studies by Clearfield et al.(60) show that, even in very acidic conditions, large species such as $\mathrm{Zr}_{18}$ containing abundant $\mathrm{OH}^{-} / \mathrm{O}^{2-}$ ligands can be crystallized. Despite high acid and sulfate concentrations, hydrolysis/olation/oxalation reactions leading to these species are not inhibited. This highlights the very strong Bronsted and Lewis acid behavior of these tetravalent metals.

The above-described solutions are optimized for studying solution speciation, and we have identified species consistent with those crystallized in this study and prior studies. The identified solution species are mainly mixtures of monomers, dimers, and hexamers, with both sulfate and $\mathrm{H}_{2} \mathrm{O} / \mathrm{OH}^{-} / \mathrm{O}^{2-}$ ligation. However, the low acidity and low ionic strength promotes gelation rather than crystallization. Therefore, the synthesis of crystalline solids was optimized in $0.5-1.0 \mathrm{M}$ $\mathrm{H}_{2} \mathrm{SO}_{4}$ and 0.5-1.0 M U(SO $\left.{ }_{4}\right)_{2}$ (see the Experimental Section). Because species evidenced in lowacid, low-sulfate solutions are similar to those crystallized from high-acid, high-sulfate solutions, this raises the question, what are the roles of the acid and sulfate? We suggest three specific roles. First, the high $\mathrm{H}^{+}$retains a positive charge on the species formed by hydrolysis/olation/oxolation reaction, preventing them from aggregating and precipitating neutral forms, also previously suggested by Clearfield et al.(60) Second, sulfate capping the growing species also prevents uncontrolled precipitation. Third, the sulfates are important for crystallization, both capping and bridging the $\mathrm{M}^{\mathrm{IV}}$ species of $\mathbf{U}_{\mathbf{2}}$ and $\mathbf{U}-\mathbf{U}_{\mathbf{6}}$ of this study and numerous other sulfate-capped oxo clusters isolated in prior studies that are usually cationic, but in rare cases, anionic.(61) In our study and prior studies, sulfate-chelating $\mathrm{M}^{\mathrm{IV}}$ seems important to retain solubility, but bridging modes are prevalent in crystallized forms because infinite lattices of solution species grow via sulfate bridging.

PXRD of bulk materials from synthesis experiments usually indicated cocrystallization of two (or more) phases. In general, lower $\mathrm{H}_{2} \mathrm{SO}_{4}$ and higher uranium concentration yielded larger species such as hexamers (i.e., $\mathbf{U}-\mathbf{U}_{6}$ ), while higher acid and lower uranium concentration favored $\mathbf{U}_{\mathbf{2}}$. From lower uranium concentration targeting $\mathbf{U}_{\mathbf{2}}$, this dihydroxide-bridged dimer cocrystallizes with the $\mathrm{U}\left(\mathrm{SO}_{4}\right)_{2} \cdot 4 \mathrm{H}_{2} \mathrm{O}$ monomer reported in 1956 (ICSD-24057; Figure 6A, designated as $\mathbf{U}_{1}$ for this discussion).(62) Meanwhile, optimization of the $\mathbf{U}-\mathbf{U}_{6}$ synthesis yielded mixtures of $\mathbf{U}_{2}$ and U-U6 (Figure 6B). Note that cocrystallized $\mathbf{U}_{\mathbf{2}}$ and $\mathbf{U}-\mathbf{U}_{\mathbf{6}}$ suggest the coexistence of monomers, dimers, and hexamers in uranium sulfate reaction solutions, analogous to thorium sulfate. $(12,13)$ This can also be viewed by SEM in Figure 7 , where the three different phases are identified by morphology, and composition confirmed by EDXS (Table 2). The experimental $\mathbf{U}_{-} \mathbf{U}_{6}$ uranium composition is most similar to that predicted from the X-ray structure, followed by $\mathbf{U}_{\mathbf{2}}$ and then $\mathbf{U}_{\mathbf{1}}$. We can perhaps attribute this to the symmetry of the phases. U-U6 has the highest symmetry 
(tetragonal) and $\mathbf{U}_{\mathbf{1}}$ the lowest (monoclinic). Higher symmetry means that the various crystal faces analyzed by EDXS present a more similar composition at the surface.
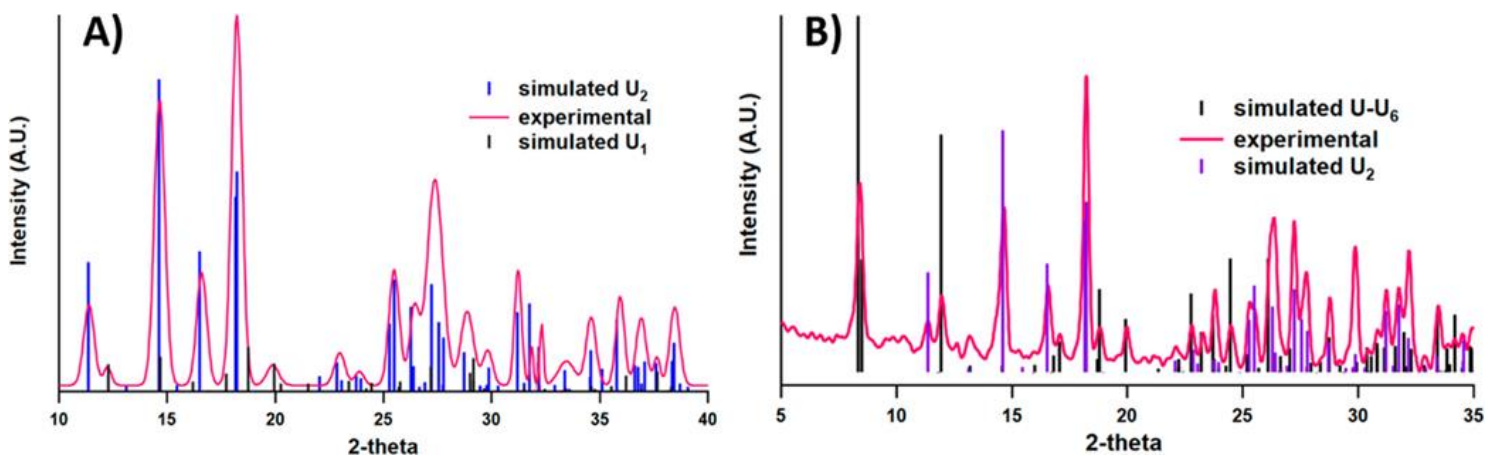

Figure 6. PXRD of bulk material for the optimized synthesis of (A) $\mathbf{U}_{2}$ (with $\mathbf{U}_{\mathbf{1}}(61)$ ) and (B) $\mathbf{U}$ $\mathbf{U}_{6}$ (mixed with $\mathbf{U}_{2}$ ). Simulated diffraction patterns are from the single-crystal X-ray diffraction structures.
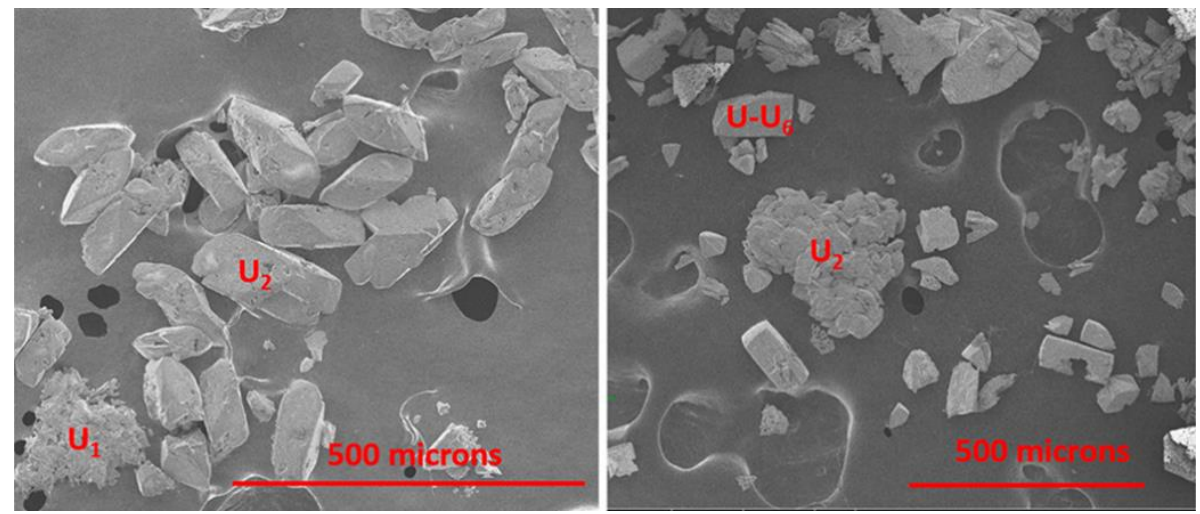

Figure 7. SEM images of the $\mathbf{U}_{\mathbf{1}} / \mathbf{U}_{\mathbf{2}}$ (left) and $\mathbf{U}_{\mathbf{2}} / \mathbf{U}-\mathbf{U}_{\mathbf{6}}$ (right) mixtures.

Table 2. Summary of EDXS

\begin{tabular}{|c|c|c|c|}
\hline phase & uranium/sulfur ratio ${ }^{a}$ & U \% (atomic, calcd) & $\mathrm{U} \%$ (atomic, exptl) $^{b}$ \\
\hline $\mathrm{U}\left(\mathrm{SO}_{4}\right)_{2}$ & $1: 2$ & 33 & $37(3)$ \\
\hline $\mathbf{U}_{2}$ & $2: 3$ & 40 & $43(2)$ \\
\hline $\mathbf{U}-\mathbf{U}_{6}$ & $8: 10$ & 44 & $45(1)$ \\
\hline
\end{tabular}

${ }^{a}$ Measured from the crystal structure.

${ }^{\mathrm{b}}$ Average values from three different measurement spots; the error in parentheses is for the tenths place digit.

\section{CONCLUSIONS}

The tetravalent actinides $\mathrm{Th}^{\mathrm{IV}}, \mathrm{U}^{\mathrm{IV}}, \mathrm{Np}^{\mathrm{IV}}$, and $\mathrm{Pu}^{\mathrm{IV}}$ with their common oxidation state and similarities to $\mathrm{Zr}^{\mathrm{IV}}, \mathrm{Hf}^{\mathrm{IV}}$, and $\mathrm{Ce}^{\mathrm{IV}}$ provide rich opportunities to understand the hydrolysis of metal cations across the periodic table. Here we described by single-crystal X-ray diffraction a dihydroxide-bridged $\mathrm{U}^{\mathrm{IV}}$ dimer, capped and bridged by sulfate into a 3D framework, and a 
uranium(IV) sulfate framework of monomer-linked hexamers. These phases along with the apparent coexistence of monomers, dimers, and hexamers as solids and in solution exhibit behavior very similar to that previously described in thorium(IV) sulfate solutions and solids, whereas prior examples of isolated clusters (containing 38-70 metal centers) suggested that $\mathrm{U}^{\mathrm{IV}}$ is more similar to $\mathrm{Np}^{\mathrm{IV}}$ and $\mathrm{Pu}^{\mathrm{IV}}$. From the perspective of a periodic trend, we indeed expect more extensive polymerization with decreasing metal-cation size, commensurate with increased acidity across the actinide series. This study, showing the similarity between $\mathrm{U}^{\mathrm{IV}}$ and $\mathrm{Th}^{\mathrm{IV}}$ chemistry, provides a bridge between thorium and the transuranics to contribute to our global understanding of the actinide series.

\section{ACKNOWLEDGMENTS}

This work was supported by the Department of Energy, National Nuclear Security Administration, under Award DE-NA0003763. We acknowledge the Murdock Charitable Trust (Grant SR2017297) for acquisition of the single-crystal X-ray diffractometer.

\section{REFERENCES}

1) Hennig, C.; Weiss, S.; Kraus, W.; Kretzschmar, J.; Scheinost, A. C. Solution Species and Crystal Structure of $\mathrm{Zr}(\mathrm{IV})$ Acetate. Inorg. Chem. 2017, 56 (5), 2473- 2480, DOI: 10.1021/acs.inorgchem.6b01624

2) Knope, K. E.; Soderholm, L. Solution and Solid-State Structural Chemistry of Actinide Hydrates and Their Hydrolysis and Condensation Products. Chem. Rev. 2013, 113 (2), 944- 994, DOI: $10.1021 / \mathrm{cr} 300212 \mathrm{f}$

3) Sommers, J. A.; Hutchison, D. C.; Martin, N. P.; Kozma, K.; Keszler, D. A.; Nyman, M. Peroxide-Promoted Disassembly Reassembly of Zr-Polyoxocations. J. Am. Chem. Soc. 2019, 141 (42), 16894- 16902, DOI: 10.1021/jacs.9b08627

4) Takao, S.; Takao, K.; Kraus, W.; Emmerling, F.; Scheinost, A. C.; Bernhard, G.; Hennig, C. First Hexanuclear UIV and ThIV Formate Complexes - Structure and Stability Range in Aqueous Solution. Eur. J. Inorg. Chem. 2009, 32, 4771- 4775, DOI: 10.1002/ejic.200900899

5) Tamain, C.; Dumas, T.; Hennig, C.; Guilbaud, P. Coordination of Tetravalent Actinides $(\mathrm{An}=\mathrm{Th}(\mathrm{IV}), \mathrm{U}(\mathrm{IV}), \mathrm{Np}(\mathrm{IV}), \mathrm{Pu}(\mathrm{IV}))$ with DOTA: From Dimers to Hexamers. Chem. Eur. J. 2017, 23 (28), 6864-6875, DOI: 10.1002/chem.201700493

6) Mathey, L.; Paul, M.; Coperet, C.; Tsurugi, H.; Mashima, K. Cerium(IV) Hexanuclear Clusters from Cerium(III) Precursors: Molecular Models for Oxidative Growth of Ceria Nanoparticles. Chem. - Eur. J. 2015, 21 (38), 13454- 61, DOI: 10.1002/chem.201501731

7) Yuan, S.; Qin, J. S.; Lollar, C. T.; Zhou, H. C. Stable Metal-Organic Frameworks with Group 4 Metals: Current Status and Trends. ACS Cent. Sci. 2018, 4 (4), 440- 450, DOI: 10.1021/acscentsci.8b00073

8) Dolgopolova, E. A.; Rice, A. M.; Shustova, N. B. Actinide-based MOFs: a middle ground in solution and solid-state structural motifs. Chem. Commun. (Cambridge, U. K.) 2018, 54 (50), 6472-6483, DOI: 10.1039/C7CC09780H

9) Jacobsen, J.; Achenbach, B.; Reinsch, H.; Smolders, S.; Lange, F. D.; Friedrichs, G.; De Vos, D.; Stock, N. The first water-based synthesis of Ce(IV)-MOFs with saturated chiral 
and achiral C4-dicarboxylate linkers. Dalton Trans 2019, 48 (23), 8433- 8441, DOI: 10.1039/C9DT01542F

10) Knope, K. E.; Soderholm, L. Plutonium(IV) cluster with a hexanuclear $\left[\mathrm{Pu}_{6}(\mathrm{OH})_{4} \mathrm{O}_{4}\right]^{12+}$ core. Inorg. Chem. 2013, 52 (12), 6770- 2, DOI: 10.1021/ic4007185

11) Sun, Q.; Liu, C.; Zhang, G.; Zhang, J.; Tung, C. H.; Wang, Y. Aqueous Isolation of 17Nuclear $\mathrm{Zr} / \mathrm{Hf}$ Oxide Clusters during the Hydrothermal Synthesis of $\mathrm{ZrO}_{2} / \mathrm{HfO}_{2}$. Chem. Eur. J. 2018, 24 (55), 14701- 14706, DOI: 10.1002/chem.201801267

12) Lin, J.; Jin, G. B.; Soderholm, L. Th-3[Th-6(OH)(4)O-4(H2O)(6)](SO4)(12)(H2O)(13): A Self-Assembled Microporous Open-Framework Thorium Sulfate. Inorg. Chem. 2016, 55 (20), 10098-10101, DOI: 10.1021/acs.inorgchem.6b01762

13) Falaise, C.; Kozma, K.; Nyman, M. Thorium Oxo-Clusters as Building Blocks for Open Frameworks. Chem. - Eur. J. 2018, 24 (53), 14226- 14232, DOI: 10.1002/chem.201802671

14) Dos Reis, R. D.; Veiga, L. S. I.; Escanhoela, C. A., Jr; Lang, J. C.; Joly, Y.; Gandra, F. G.; Haskel, D.; Souza-Neto, N. M. Unraveling 5f-6d hybridization in uranium compounds via spin-resolved L-edge spectroscopy. Nat. Commun. 2017, 8 (1), 1203, DOI: 10.1038/s41467-017-01524-1

15) Wilson, R. E.; De Sio, S.; Vallet, V. Protactinium and the intersection of actinide and transition metal chemistry. Nat. Commun. 2018, 9 (1), 622, DOI: 10.1038/s41467-01802972-z

16) Roos, B. O.; Malmqvist, P. A.; Gagliardi, L. Exploring the actinide-actinide bond: theoretical studies of the chemical bond in $\mathrm{Ac}_{2}, \mathrm{Th}_{2}, \mathrm{~Pa}_{2}$, and $\mathrm{U}_{2}$. J. Am. Chem. Soc. 2006, 128 (51), 17000-6, DOI: 10.1021/ja066615z

17) Katz, J. J. The Chemistry of the Actinide and Transactinide Elements; Springer Science \& Business Media, 2007; Vol. 1.

18) Henry, M.; Jolivet, J. P.; Livage, J. Aqueous Chemistry of Metal Cations: Hydrolysis, Condensation and Complexation. Chemistry, Spectroscopy and Applications of Sol-Gel Glasses; Springer: Berlin, 1992; pp 153- 206.

19) Knope, K. E.; Wilson, R. E.; Skanthakumar, S.; Soderholm, L. Synthesis and characterization of thorium(IV) sulfates. Inorg. Chem. 2011, 50 (17), 8621- 9, DOI: $10.1021 /$ ic $201175 \mathrm{u}$

20) Albrecht, A. J.; Sigmon, G. E.; Moore-Shay, L.; Wei, R.; Dawes, C.; Szymanowski, J.; Burns, P. C. The crystal chemistry of four thorium sulfates. J. Solid State Chem. 2011, 184 (7), 1591-1597, DOI: 10.1016/j.jssc.2011.04.024

21) Hu, Y. J.; Knope, K. E.; Skanthakumar, S.; Soderholm, L. Understanding the LigandDirected Assembly of a Hexanuclear ThIV Molecular Cluster in Aqueous Solution. Eur. J. Inorg. Chem. 2013, 24, 4159-4163, DOI: 10.1002/ejic.201300805

22) Wacker, J. N.; Vasiliu, M.; Colliard, I.; Ayscue, R. L., 3rd; Han, S. Y.; Bertke, J. A.; Nyman, M.; Dixon, D. A.; Knope, K. E. Monomeric and Trimeric Thorium Chlorides Isolated from Acidic Aqueous Solution. Inorg. Chem. 2019, 58 (16), 10871- 10882, DOI: 10.1021/acs.inorgchem.9b01238

23) Sigmon, G. E.; Hixon, A. E. Extension of the Plutonium Oxide Nanocluster Family to Include $\{\mathrm{Pu}-16\}$ and $\{\mathrm{Pu}-22\}$. Chem. - Eur. J. 2019, 25 (10), 2463- 2466, DOI: 10.1002/chem.201805605 
24) Soderholm, L.; Almond, P. M.; Skanthakumar, S.; Wilson, R. E.; Burns, P. C. The structure of the plutonium oxide nanocluster $\left.\left[\mathrm{Pu}_{38} \mathrm{O}_{56} \mathrm{Cl}_{54}\left(\mathrm{H}_{2} \mathrm{O}\right)_{8}\right)\right]^{14-}$. Angew. Chem., Int. Ed. 2008, 47 (2), 298- 302, DOI: 10.1002/anie.200704420

25) Hastings, A. M.; Ray, D.; Jeong, W.; Gagliardi, L.; Farha, O. K.; Hixon, A. E. Advancement of Actinide Metal-Organic Framework Chemistry via Synthesis of Pu-UiO66. J. Am. Chem. Soc. 2020, 142 (20), 9363-9371, DOI: 10.1021/jacs.0c01895

26) Knope, K. E.; Skanthakumar, S.; Soderholm, L. Two Dihydroxo-Bridged Plutonium(IV) Nitrate Dimers and Their Relevance to Trends in Tetravalent Ion Hydrolysis and Condensation. Inorg. Chem. 2015, 54 (21), 10192- 6, DOI: 10.1021/acs.inorgchem.5b01242

27) Ray, D.; Xie, J.; White, J.; Sigmon, G. E.; Gagliardi, L.; Hixon, A. E. Experimental and quantum mechanical characterization of an oxygen-bridged plutonium(IV) dimer. Chem. Eur. J. 2020, 26, 8115, DOI: 10.1002/chem.202000638

28) Martin, N. P.; Volkringer, C.; Henry, N.; Trivelli, X.; Stoclet, G.; Ikeda-Ohno, A.; Loiseau, T. Formation of a new type of uranium(iv) poly-oxo cluster $\{\mathrm{U}-38\}$ based on a controlled release of water via esterification reaction. Chem. Sci. 2018, 9 (22), 5021- 5032, DOI: $10.1039 / \mathrm{C} 8 \mathrm{SC} 00752 \mathrm{G}$

29) Vanagas, N. A.; Higgins, R. F.; Wacker, J. N.; Asuigui, D. R. C.; Warzecha, E.; Kozimor, S. A.; Stoll, S. L.; Schelter, E. J.; Bertke, J. A.; Knope, K. E. Mononuclear to Polynuclear U(IV) Structural Units: Effects of Reaction Conditions on U-Furoate Phase Formation. Chem. - Eur. J. 2020, 26, 5872, DOI: 10.1002/chem.201905759

30) Falaise, C.; Volkringer, C.; Vigier, J. F.; Beaurain, A.; Roussel, P.; Rabu, P.; Loiseau, T. Isolation of the Large \{Actinide\}(38) Poly-oxo Cluster with Uranium. J. Am. Chem. Soc. 2013, 135 (42), 15678-15681, DOI: 10.1021/ja4067207

31) Martin, N. P.; Volkringer, C.; Roussel, P.; Marz, J.; Hennig, C.; Loiseau, T.; Ikeda-Ohno, A. $\{\mathrm{Np}-38\}$ clusters: the missing link in the largest poly-oxo cluster series of tetravalent actinides. Chem. Commun. 2018, 54 (72), 10060- 10063, DOI: 10.1039/C8CC03744B

32) Falaise, C.; Neal, H. A.; Nyman, M. U(IV) Aqueous Speciation from the Monomer to $\mathrm{UO}_{2}$ Nanoparticles: Two Levels of Control from Zwitterionic Glycine Ligands. Inorg. Chem. 2017, 56 (11), 6591-6598, DOI: 10.1021/acs.inorgchem.7b00616

33) Martin, N. P.; Marz, J.; Feuchter, H.; Duval, S.; Roussel, P.; Henry, N.; Ikeda-Ohno, A.; Loiseau, T.; Volkringer, C. Synthesis and structural characterization of the first neptunium based metal-organic frameworks incorporating $\left\{\mathrm{Np}_{6} \mathrm{O}_{8}\right\}$ hexanuclear clusters. Chem. Commun. 2018, 54 (51), 6979- 6982, DOI: 10.1039/C8CC03121E

34) Vanagas, N. A.; Wacker, J. N.; Rom, C. L.; Glass, E. N.; Colliard, I.; Qiao, Y. S.; Bertke, J. A.; Van Keuren, E.; Schelter, E. J.; Nyman, M.; Knope, K. E. Solution and Solid State Structural Chemistry of Th(IV) and U(IV) 4-Hydroxybenzoates. Inorg. Chem. 2018, 57 (12), 7259- 7269, DOI: 10.1021/acs.inorgchem.8b00919

35) Yue, Z.; Guo, X.; Feng, M. L.; Lin, Y. J.; Ju, Y.; Lin, X.; Zhang, Z. H.; Guo, X.; Lin, J.; Huang, Y. Y.; Wang, J. Q. Unexpected Roles of Alkali-Metal Cations in the Assembly of Low-Valent Uranium Sulfate Molecular Complexes. Inorg. Chem. 2020, 59 (4), 23482357, DOI: 10.1021/acs.inorgchem.9b03182

36) Chatelain, L.; Faizova, R.; Fadaei-Tirani, F.; Pecaut, J.; Mazzanti, M. Structural Snapshots of Cluster Growth from $\left\{\mathrm{U}_{6}\right\}$ to $\left\{\mathrm{U}_{38}\right\}$ During the Hydrolysis of $\mathrm{UCl}_{4}$. Angew. Chem., Int. Ed. 2019, 58 (10), 3021-3026, DOI: 10.1002/anie.201812509 
37) Pocev, S.; Johansson, G.; Grønvold, F.; Pessa, M.; van der Hoeven, M. G.; Swahn, C.-G. An X-ray Investigation of the coordination and the hydrolysis of the uranium(IV) ions in aqueous perchlorate solutions. Acta Chem. Scand. 1973, 27, 2146- 2160, DOI: 10.3891/acta.chem.scand.27-2146

38) Uhrie, J. L.; Drever, J. I.; Colberg, P. J. S.; Nesbitt, C. C. In situ immobilization of heavy metals associated with uranium leach mines by bacterial sulfate reduction. Hydrometallurgy 1996, 43, 231- 239, DOI: 10.1016/0304-386X(95)00087-W

39) Suzuki, Y.; Kelly, S. D.; Kemner, K. M.; Banfield, J. F. Radionuclide contamination Nanometre-size products of uranium bioreduction. Nature 2002, 419 (6903), 134134, DOI: $10.1038 / 419134 \mathrm{a}$

40) Colliard, I.; Morrison, G.; Loye, H. Z.; Nyman, M. Supramolecular Assembly of U(IV) Clusters and Superatoms with Unconventional Countercations. J. Am. Chem. Soc. 2020, 142 (19), 9039-9047, DOI: 10.1021/jacs.0c03041

41) Colliard, I.; Nyman, M. Building $\left[\mathrm{U}^{\mathrm{IV}} 70(\mathrm{OH})_{36}(\mathrm{O})_{64}\right]^{4}$ oxocluster frameworks with sulfate, transition metals, and $\mathrm{U}^{\mathrm{V}}$. Chem. - Eur. J. 2020, 26, 12481, DOI: 10.1002/chem.202002403

42) Sheldrick, G. M. A short history of SHELX. Acta Crystallogr., Sect. A: Found. Crystallogr. 2008, 64 (1), 112- 122, DOI: 10.1107/S0108767307043930

43) Sheldrick, G. M. SHELXT - Integrated space-group and crystal-structure determination. Acta Crystallogr., Sect. A: Found. Adv. 2015, A71, 3- 8, DOI: $10.1107 / \mathrm{S} 2053273314026370$

44) Dolomanov, O. V.; Bourhis, L. J.; Gildea, R. J.; Howard, J. A.; Puschmann, H. OLEX2: a complete structure solution, refinement and analysis program. J. Appl. Crystallogr. 2009, 42 (2), 339- 341, DOI: 10.1107/S0021889808042726

45) SCALE3 ABSPACK-An Oxford Diffraction Program (1.0.4,gui:1.0.3) (C); Oxford Diffraction Ltd., 2005.

46) Ilavsky, J.; Jemian, P. R. Irena: tool suite for modeling and analysis of small-angle scattering. J. Appl. Crystallogr. 2009, 42, 347-353, DOI: 10.1107/S0021889809002222

47) Zuo, X.; Cui, G.; Merz, K. M.; Zhang, L.; Lewis, F. D.; Tiede, D. M. X-ray diffraction "fingerprinting" of DNA structure in solution for quantitative evaluation of molecular dynamics simulation. Proc. Natl. Acad. Sci. U. S. A. 2006, 103, 3534- 3539, DOI: 10.1073/pnas.0600022103

48) McWhan, D. B.; Lundgren, G. The Crystal Structure of $\mathrm{Zr}_{2}(\mathrm{OH})_{2}\left(\mathrm{SO}_{4}\right)_{3}\left(\mathrm{H}_{2} \mathrm{O}\right)_{4}$. Inorg. Chem. 1966, 5 (2), 284- 289, DOI: 10.1021/ic50036a027

49) El Brahimi, M.; Durand, J.; Cot, L. Crystal Structure of the Basic Zirconium Sulfate $\mathrm{Zr}(\mathrm{OH})_{2} \mathrm{SO}_{4}$. Eur. J. Solid State Inorg. Chem. 1988, 20 (1), 185- 190

50) Hansson, M.; Brattås, L.; Kjekshus, A.; Enzell, C. R.; Swahn, C.-G. The Crystal Structure of $\mathrm{Hf}(\mathrm{OH})_{2}\left(\mathrm{SO}_{4}\right)$. Acta Chem. Scand. 1973, 27 (7), 2455- 2462, DOI: 10.3891/acta.chem.scand.27-2455

51) Lundgren, G. The structures of oxide and hydroxide salts of some tetrapositive ions. Recueil des Travaux Chimiques des Pays-Bas 1956, 75 (5), 585- 588, DOI: 10.1002/recl.19560750514

52) Lundgren, G. The Crystal Structure of $\mathrm{U}_{6} \mathrm{O}_{4}(\mathrm{OH})_{4}\left(\mathrm{SO}_{4}\right)_{6}$. Ark. Kemi 1953, 5, 349- 363

53) Schnaars, D. D.; Wilson, R. E. Uranium(IV) sulfates: investigating structural periodicity in the tetravalent actinides. Inorg. Chem. 2012, 51 (17), 9481- 90, DOI: $10.1021 /$ ic $301291 \mathrm{w}$ 
54) Ruther, R. E.; Baker, B. M.; Son, J. H.; Casey, W. H.; Nyman, M. Hafnium sulfate prenucleation clusters and the $\mathrm{Hf}(18)$ polyoxometalate red herring. Inorg. Chem. 2014, 53 (8), 4234, DOI: $10.1021 /$ ic500375v

55) Perez, F. M.; Gil, J. M.; Gil, F. J. M. Preparation, Infrared and Visible Spectra of Sulfate Complexes of Uranium (IV). Z. Anorg. Allg. Chem. 1980, 462, 231- 240, DOI: 10.1002/zaac. 19804620127

56) Cohen, D.; Carnall, W. T. Absorption Spectra of Uranium(III) and Uranium(IV) in $\mathrm{DClO}_{4}$ solution. J. Phys. Chem. 1960, 64 (12), 1933- 1936, DOI: 10.1021/j100841a031

57) Hanwell, M. D.; Curtis, D. E.; Lonie, D. C.; Vandermeersch, T.; Zurek, E.; Hutchison, G. R. Avogadro: an advanced semantic chemical editor, visualization, and analysis platform. J. Cheminf. 2012, 4 (1), 17, DOI: 10.1186/1758-2946-4-17

58) Hu, Y. J.; Knope, K. E.; Skanthakumar, S.; Kanatzidis, M. G.; Mitchell, J. F.; Soderholm, L. Understanding the role of aqueous solution speciation and its application to the directed syntheses of complex oxidic $\mathrm{Zr}$ chlorides and sulfates. J. Am. Chem. Soc. 2013, 135 (38), 14240- 8, DOI: 10.1021/ja405555h

59) Kalaji, A.; Skanthakumar, S.; Kanatzidis, M. G.; Mitchell, J. F.; Soderholm, L. Changing hafnium speciation in aqueous sulfate solutions: a high-energy X-ray scattering study. Inorg. Chem. 2014, 53 (12), 6321-8, DOI: 10.1021/ic500938k

60) Clearfield, A.; Serrette, G. P. D.; Khazi-Syed, A. H. Nature of hydrous zirconia and sulfated hydrous zirconia. Catal. Today 1994, 20, 295- 312, DOI: 10.1016/09205861(94)80008-1

61) Kalaji, A.; Soderholm, L. A novel nonanuclear hafnium oxide-hydroxide-sulphate cluster crystallised from aqueous solution. Chem. Commun. 2014, 50 (8), 997- 999, DOI: $10.1039 / \mathrm{C} 3 \mathrm{CC} 48167 \mathrm{~K}$

62) Kierkegaard, P.; Parck, C.; Ulfvarson, U.; Stenhagen, E.; Thorell, B. The Crystal Structure of $\mathrm{U}\left(\mathrm{SO}_{4}\right)_{2}-4 \mathrm{H}_{2} \mathrm{O}$. Acta Chem. Scand. 1956, 10, 599- 616, DOI: 10.3891/acta.chem.scand.10-0599 